\title{
10. REGIONAL GEOPHYSICS AND STRUCTURAL FRAMEWORK OF THE VANCOUVER ISLAND MARGIN ACCRETIONARY PRISM ${ }^{1}$
}

\author{
R.D. Hyndman,,$^{2,3}$ G.D. Spence, ${ }^{3}$ T. Yuan, ${ }^{3}$ and E.E. Davis ${ }^{2}$
}

\begin{abstract}
Ocean Drilling Program (ODP) Leg 146 was directed at aspects of two related problems: (1) the role of sediment consolidation and fluid expulsion in the development of subduction zone accretionary prisms and (2) the nature and origin of bottom-simulating reflectors (BSR) interpreted to be generated by high-velocity methane hydrate and underlying low-velocity free gas. The portion of the leg assigned to drilling off Vancouver Island addressed diffuse fluid expulsion from the prism not associated with obvious faults or other structures, and the structure and composition of the hydrate. The two objectives are related through the possibility that fluid expulsion is required for the formation of the hydrate that forms BSRs. This article describes the regional geological framework and tectonics of the northern Cascadia Margin at Vancouver Island, presents regional survey data in the area of the ODP sites, and summarizes the scientific studies that led to the drilling objectives. An extensive reference list is given to assist the reader in obtaining more detailed information.
\end{abstract}

\section{INTRODUCTION}

The southern Vancouver Island margin in the area of Sites 888 , 889 , and 890 has been the focus of comprehensive marine geological and geophysical surveys (see Davis and Hyndman, 1989; Hyndman et al., 1990) complemented by adjacent onshore studies through the LITHOPROBE program (e.g., Clowes, Brandon, et al., 1987; Yorath, in press), allowing the construction of a continuous onshore-offshore structural cross-section. The more recent detailed surveys were directed at providing supporting data for the primary Cascadia ODP drilling objectives, including (1) elucidation of the role of sediment consolidation and fluid expulsion in the development of the accretionary wedge and (2) the origin of bottom-simulating reflectors (BSRs) interpreted to be generated by high-velocity methane hydrate "ice" and underlying concentrations of free gas. A supplementary objective was to obtain data that would help constrain the location of the "locked" portion of the décollement on which great subduction thrust earthquakes may occur.

\section{Present Plate Tectonic Regime}

Most of the continental margin of western North America lies along the right-lateral transform boundary between the Pacific and North America plates. The San Andreas fault system extends from the Gulf of California to Cape Mendocino in northern California, and the Queen Charlotte fault system extends from just north of Vancouver Island to the Aleutian Trench of Alaska (Fig. 1). Along the intervening margin of northern California, Oregon, Washington, and southern British Columbia, subduction of the Juan de Fuca Plate takes place in the Cascadia subduction zone. The Juan de Fuca Plate is the remnant of the large Farallon Plate that has fragmented and diminished in size as a result of the convergence of the East Pacific Rise spreading center and the North American continent, and the northward movement of the southern (Mendocino) triple junction (Atwater, 1970). The northern triple junction appears to have remained stable off northern Vancouver Island since the Eocene (e.g., Riddihough, 1984; Stock and Molnar, 1988; Engebretson et al., 1984, 1985; Atwater, 1989; Hynd-

${ }^{1}$ Westbrook, G.K., Carson, B., Musgrave, R.J., et al., 1994. Proc, ODP, Init. Repts., 146 (Pt. 1): College Station, TX (Ocean Drilling Program).

${ }^{2}$ Pacific Geoscience Centre, Geological Survey of Canada, P.O. Box 6000 , Sidney, British Columbia V8L 4B2, Canada.

${ }^{3}$ School of Earth and Ocean Sciences, University of Victoria, Victoria, British Columbia V8W 3P6, Canada.

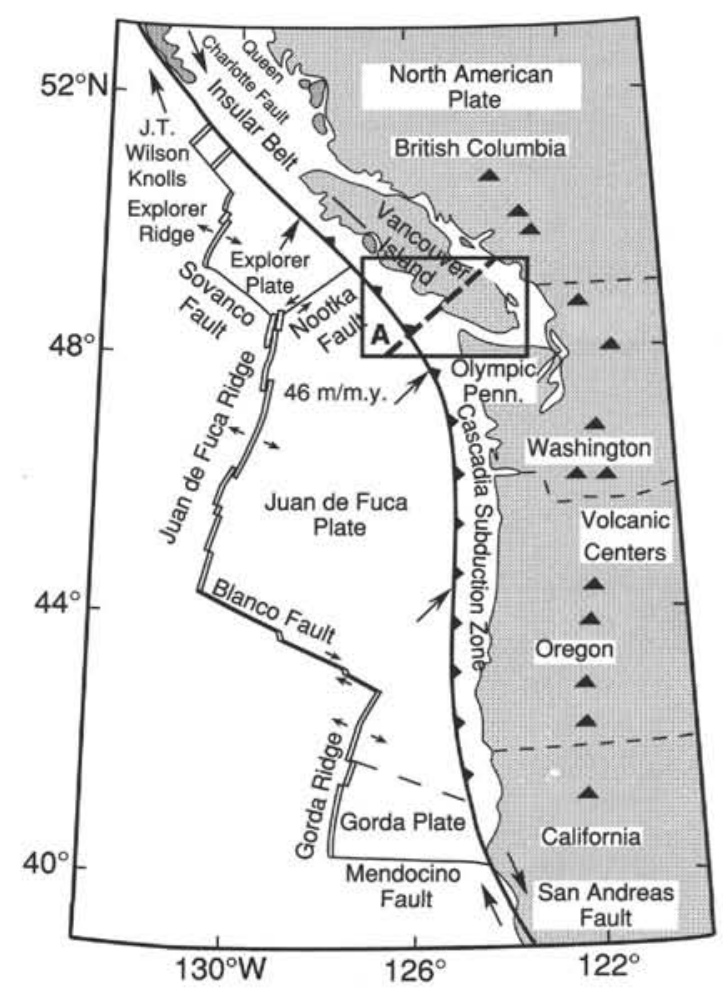

Figure 1. Large-scale plate regime of the Cascadia Margin. The box includes the northern drilling area and marks the area of Figures 4 and 8 . The dashed line indicates the location of the seismicity, thermal, seismic reflection, and structure profiles of Figures 2, 3, 6, 7, and 18 .

man and Hamilton, 1993). The present plate configuration had its origin in a major reorganization of the northeast Pacific Plate regime in the Eocene at about $43 \mathrm{Ma}$.

The Juan de Fuca Plate system is complex, but the present plate regime has been delineated through analyses of detailed magnetic anomaly surveys and other studies. Several subplates (Explorer, Winona Block) exist to the north of the Nootka transform fault that meets the coast off north central Vancouver Island (Carbotte et al., 1989; Hyndman et al., 1979); off southern Oregon and northern California the southern portion of the Juan de Fuca Plate is deforming and 
fracturing (Wilson, 1989). In the intervening region, however, the main portion of the Juan de Fuca Plate has been converging toward the northeast and underthrusting the continent since the Eocene. The present rate of convergence increases slightly northward and is about $45 \mathrm{~mm} / \mathrm{yr}$ off southern Vancouver Island; the direction is approximately orthogonal to the margin off southern Vancouver Island and about $20^{\circ}$ from orthogonal off Washington and Oregon (Riddihough, 1984; Nishimura et al., 1984; DeMets et al., 1990). The North America Plate has been advancing westward over the asthenosphere and overriding the Pacific Plate at a rate of about $20 \mathrm{~mm} / \mathrm{yr}$ for at least the past $10 \mathrm{~m} . y$. and probably at a similar rate throughout the Cenozoic (e.g., Riddihough, 1984; Pollitz, 1988), resulting in a relatively shallow angle of subduction.

The modern Juan de Fuca Plate convergence and underthrusting is evident in most of the common characteristics of subduction zones. These include (1) a series of active volcanoes extending from northern California to southern British Columbia (e.g., Wells et al., 1984) (Fig. 1); (2) extensive seismicity (although there have been no historical subduction thrust events) (e.g., Crosson and Owens, 1987; Rogers, 1983) (Fig. 2); (3) the characteristic pattern of low heat flow in the forearc inland from the margin, with an abrupt increase just seaward of the volcanic arc (Lewis et al., 1988, 1991; Blackwell, 1991) (Fig. $3)$; (4) the characteristic low-high gravity couple represented by low values over the outer margin (trench) and high values over the edge of the continent (e.g., Riddihough, 1979) (Fig. 4); and (5) an extensive accretionary sedimentary prism (discussed below). General reviews on the plate regime of the Vancouver Island margin have been given by Keen and Hyndman (1979) and Riddihough and Hyndman (1991).

\section{Cenozoic Tectonic History and Development of the Vancouver Island Margin}

Along the central portion of the Cascadia Margin, convergence has been continuous and approximately orthogonal to the margin since the Eocene (Engebretson et al., 1985; Wilson, 1988) (Fig. 5). Along the Queen Charlotte margin, the major plate regime reorganization in the Pacific at about 43 Ma probably resulted in a change from convergent to strike-slip motion (e.g., Hyndman and Hamilton, 1993). The older Vancouver Island margin may have been truncated and translated to the north just before or at this time (Johnson, 1984; Wells et al., 1984). This also is the time of emplacement of two narrow terranes against the Cascadia Margin, the Eocene marine volcanic Crescent Terrane (and its equivalents to the south), and the Mesozoic marine sedimentary Pacific Rim Terrane. Both terranes outcrop on southernmost Vancouver Island near Victoria. The Crescent Terrane also outcrops to the south on the Olympic Peninsula and has been sampled by hydrocarbon exploration wells beneath the Vancouver Island shelf (Shouldice, 1971, 1973). This terrane may be a sliver of marginal basin or oceanic plateau crust that first underthrust the continent and in turn was underthrust by the Juan de Fuca Plate (e.g., Massey, 1986; Hyndman et al., 1990). A narrow sediment-filled trough, landward and above the Crescent Terrane, may be a "fossil trench" marking the earlier axis of underthrusting (Figs. 6-7). The Crescent Terrane provides the landward-dipping "backstop" to the accretionary wedge that has accumulated since the Eocene (Hyndman et al., 1990). The Tofino Basin, containing up to $4 \mathrm{~km}$ of Eocene to Holocene sediments, overlies the accretionary wedge and the two accreted terranes beneath the continental shelf off southern Vancouver Island (Figs. 6-8) (Tiffin et al., 1972; MacLeod et al., 1977; Shouldice, 1971, 1973; Yorath, 1980, 1987; Hyndman et al., 1990; Langton, 1993). The structure of the two terranes and the accretionary prism have been well defined by marine and land multichannel seismic and magnetic and gravity data (e.g., Hyndman et al., 1990; Dehler, 1992); a structural cross-section is shown in Figure 7 and a plan view in Figure 8. Mass balance calculations (Davis and Hyndman, 1989; Hyndman et al., 1990) indicate that the volume of the accretionary sedimentary prism is approximately equal to the estimated volume of sediments brought in on the Juan de Fuca Plate since the Eocene. Although the calculation has an uncertainty of about a factor of 2 , this result is consistent with the supposition that since the Eocene, much if not most of the incoming sediment has been scraped off the oceanic plate rather than subducted. This is in contrast to many subduction zones where the décollement just landward of the deformation front lies within the sedimentary section, well above the oceanic crust, and substantial amounts of sediment are subducted to greater depths (e.g., von Huene and Scholl, 1991).

\section{STRUCTURE OF THE ACCRETIONARY SEDIMENTARY PRISM}

\section{Multichannel Seismic Reflection Data}

In 1985, widely spaced marine multichannel reflection lines were recorded across the continental shelf and slope off Vancouver Island as part of the Frontier Geoscience Program of the Geological Survey of Canada. As part of the site surveys for ODP, $722 \mathrm{~km}$ of new multi-

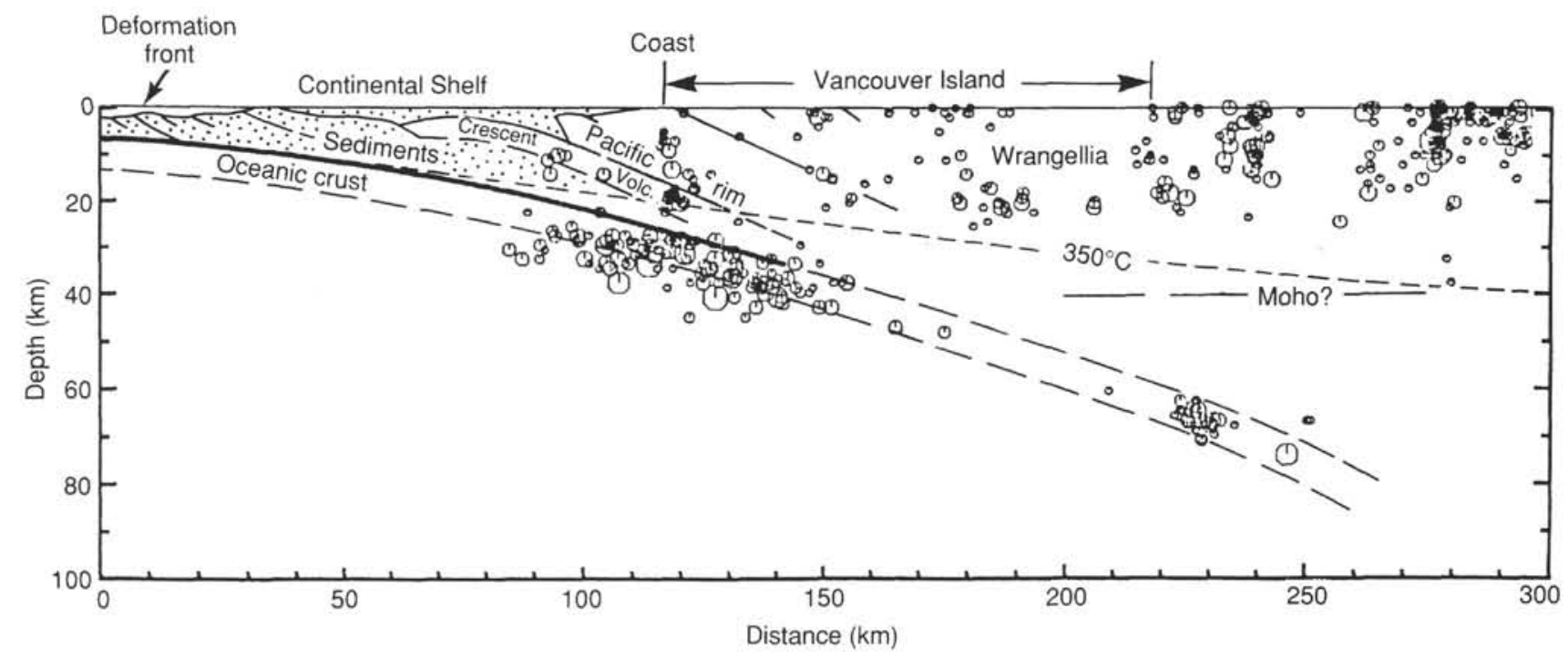

Figure 2. Seismicity cross-section across the southern Vancouver Island margin from the deformation front to just seaward of the volcanic arc (after Dragert et al, in press) (location on Fig. 1). 

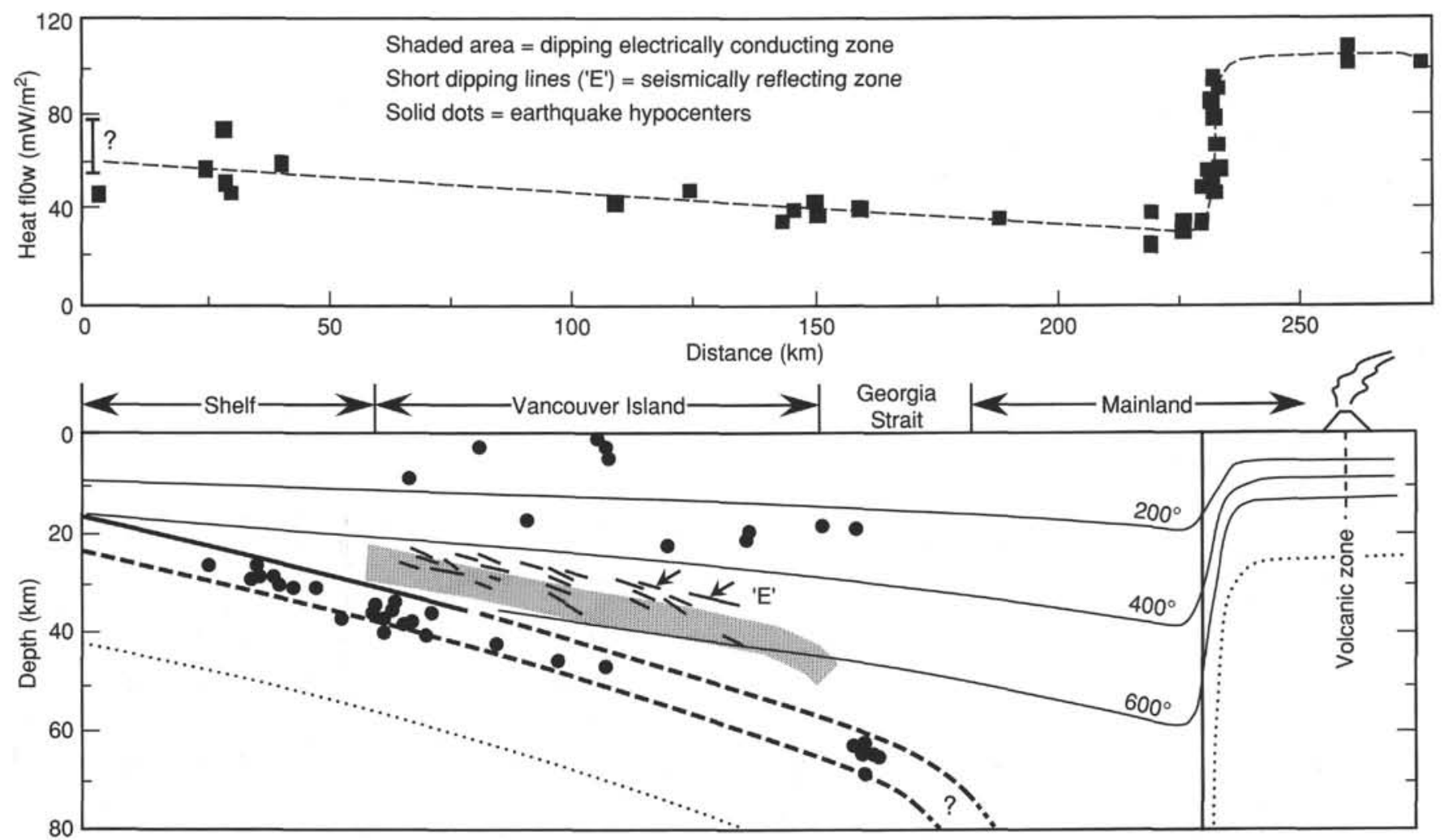

Figure 3. Large-scale heat-flow cross-section and crustal temperatures across the northern Cascadia subduction zone from the shelf edge to the volcanic arc (modified from Lewis et al., 1988) (location on Fig. 1). The accretionary prism heat flow and temperatures are given in Figures 17-19.

channel data were collected in 1989 (Fig. 9). Four of the lines crossed the continental shelf to obtain regional structure; the shots from these lines also were recorded at several sites on land to provide deep velocity information. Two grids of lines were recorded across the deformation front region. With the previous surveys this provided three lines at approximately $3 \mathrm{~km}$ spacing and two crossing strike lines in the northern area (Sites 889 and 890) (Fig. 9) and four lines at $3 \mathrm{~km}$, also with two crossing strike lines, in the southern area (Site 888).

The 1985 survey (Yorath et al., 1987; Clowes, Yorath, and Hyndman, 1987; Davis and Hyndman, 1989) was conducted and processed to final migration by Geophoto Limited of Calgary (GSI Inc.). A 50 element air-gun array with a total volume of $98 \mathrm{~L}\left(6110 \mathrm{in}^{3}{ }^{3}\right)$, tuned to concentrate energy at frequencies below $50 \mathrm{~Hz}$, was fired every $50 \mathrm{~m}$. The signals were received by a 3000 -m-long, 120-channel streamer that yielded 30 -fold data recorded to $16 \mathrm{~s}$.

The 1989 survey was conducted by Digicon (Canada) Ltd. and initially processed by Geophoto Ltd. (Haliburton Geophysical Services Ltd.). The survey design was a compromise between the optimum parameters for resolving the shallow and deep structures (Spence, Hyndman, Davis, et al., 1991; Spence, Hyndman, Langton, et al., 1991). The source was a tuned air-gun array consisting of four strings of ten guns each (three active strings and one spare) with a total volume of $125 \mathrm{~L}\left(7800 \mathrm{in.}^{3}\right)$. The data were recorded to $14 \mathrm{~s}$ on a 3600-m-long, 144-channel streamer with maximum offset of $3757 \mathrm{~m}$. Shots were fired at $50-\mathrm{m}$ intervals giving 36 -fold data. The seismic sections from the 1989 survey that passed through the Leg 146 drill sites (lines 89-04, 89-08, and 89-10) are presented in Figure 10 and large-scale versions are contained in the back pocket; their locations are shown in Figure 9.

Processing of the 1989 data by Geophoto Ltd. included (1) application of exponential gain and spherical divergence corrections; (2) $f-k$ velocity filtering to suppress backscatter energy; (3) shot-domain source wavelet deconvolution; and (4) f-k demultiple. Subsequent processing at the University of Victoria focused on the detailed determination of stacking velocities, for which semblance analyses were performed every $10-20$ common depth points (CDP) (125-250 m). A dip-moveout (DMO) process was applied to properly account for reflector dip, especially in regions where there were conflicting dips between stratigraphic interfaces and more steeply dipping fault plane interfaces. After application of the DMO, all velocities were picked again, and the data were stacked, deconvolved for water bottom multiple attenuation, and migrated with a finite difference algorithm.

Special processing was also applied by Geophoto Ltd. to $16 \mathrm{~km}$ of data along four lines, including line 89-10 (Fig. 9), with the intent of carefully preserving amplitudes for subsequent analyses of amplitude vs. offset (AVO). As discussed by Hyndman and Spence (1992), processing included (1) predeconvolution mute; (2) zero-phase source wavelet deconvolution in the shot domain; (3) spherical divergence spreading loss correction; (no inelastic attenuation correction applied); and (4) velocity analysis.

\section{Structure of the Accretionary Prism}

The northern Cascadia accretionary sedimentary prism is bounded at its base by the underthrusting oceanic crust and on its landward side by the landward-dipping Crescent Terrane. The prism is overlain by the Tofino forearc basin. The oceanic crust is well imaged by marine and land multichannel seismic (MCS) data from beneath the ocean basin to a depth of $40 \mathrm{~km}$ beneath Vancouver Island (Hyndman et al. 1990) (Figs. 6-7). The reflection depths are in good agreement with seismic refraction models (Spence et al., 1985; Drew and Clowes, 1990) and Benioff-Wadati seismicity (Crosson and Owens, 1987; Rogers, 1983; Dragert et al., in press) (Fig. 2). The incoming Juan de Fuca Plate surface is unusually smooth with very few seamounts (Davis and Karsten, 1986), and the seismically imaged top of the oceanic crust beneath the accretionary wedge also is smooth. Off southern Vancouver Island, the dip of the oceanic crust increases from $3^{\circ}$ to $4^{\circ}$ just seaward of the deformation front to $10^{\circ}$ under the edge of the shelf 

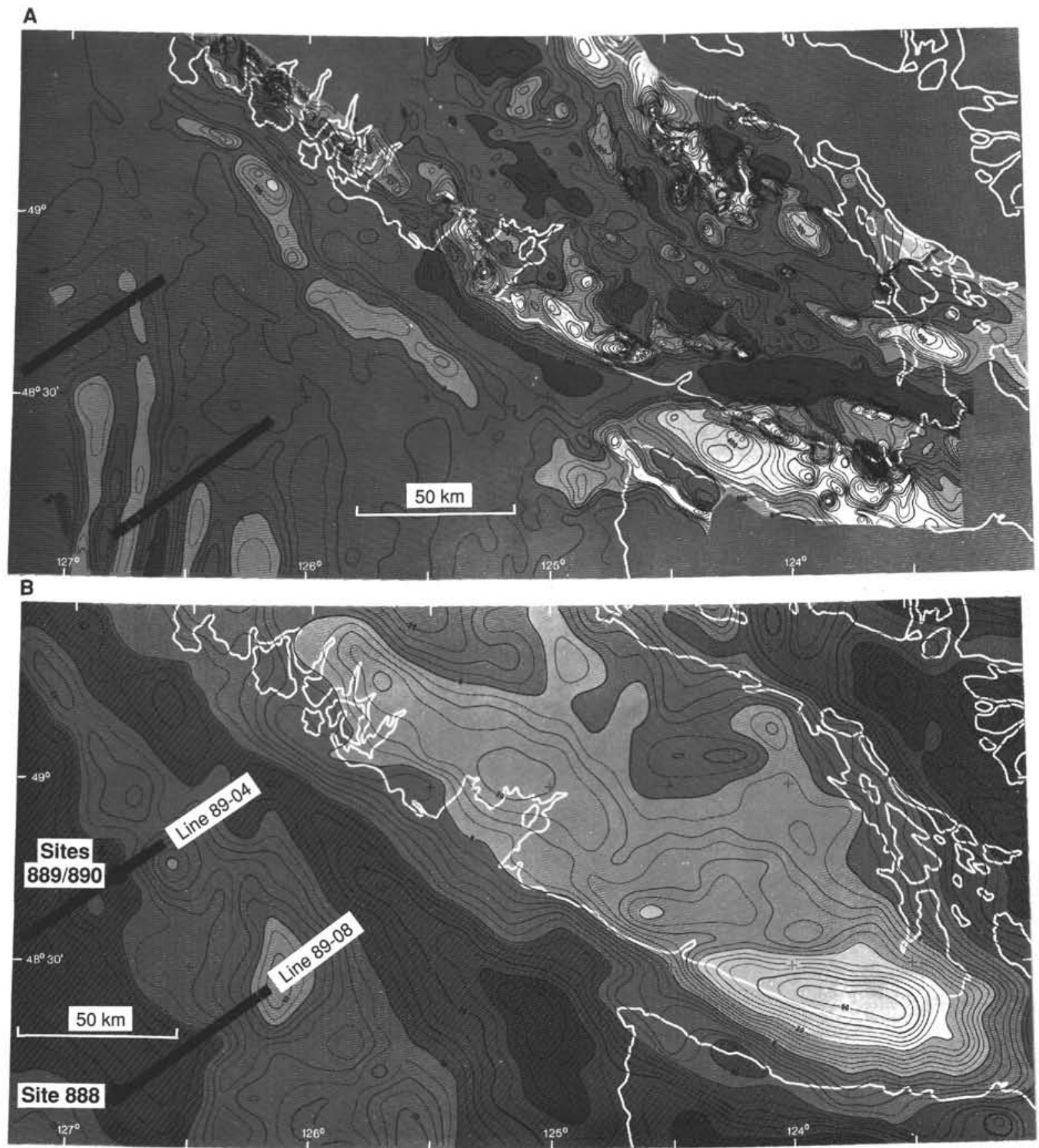

Figure 4. A. Contour magnetic anomaly map of the southern Vancouver Island margin. The contour interval is 50 gammas $(1 \mathrm{gamma}=1 \mathrm{nT})$. B. Contour gravity map of the southern Vancouver Island margin, with Bouguer onshore and Free Air offshore. The contour interval is $5 \mathrm{mgal}$ $\left(1 \mathrm{mgal}=10^{-5} \mathrm{~m} / \mathrm{s}\right)$.

and thence to $15^{\circ}$ beneath the coast (Fig. 7). The dip is substantially less beneath the Olympic Peninsula margin to the south (e.g., Davis and Hyndman, 1989). The Crescent Terrane, located beneath the coastal region of Vancouver Island (Figs. 6-8), acts as the landwarddipping backstop against which the sediments are scraped off the incoming Juan de Fuca Plate. On the 1989 Tofino Basin seismic data, the base of the Crescent Terrane can be traced down to near the top of the subducting oceanic plate (Spence, Hyndman, Davis, et al., 1991; Langton, 1993).

The accretionary prism sediments do not crop out on the Vancouver Island margin and the exploratory wells on the shelf penetrated only the overlying Tofino Basin sediments. However, to the south, late Eocene and younger Core rocks exposed below and seaward of the Crescent Terrane volcanics on the Olympic Peninsula (Fig. 8) probably represent the older components of this accretionary prism (e.g., Tabor and Cady, 1978; Snavely, 1987).

The frontal portion of the accretionary prism off southern Vancouver Island has been well surveyed by multichannel seismic reflection, acoustic imagery, and swath bathymetry, revealing its surface morphology, cross-sectional geometry, and deformation style (e.g., Davis and Seemann, 1981; Clowes, Yorath, and Hyndman, 1987; Davis and Hyndman, 1989; Spence, Hyndman, Davis, et al., 1991; Spence, 


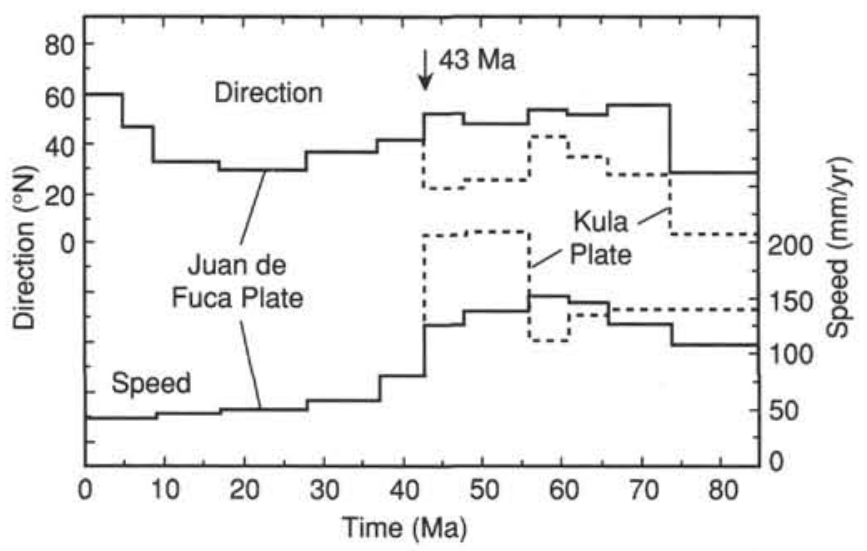

Figure 5. Cenozoic plate directions and speeds across the northern Cascadia Margin (from Engebretson et al., 1985). The Kula Plate was probably offshore before $43 \mathrm{Ma}$.

Hyndman, Langton, et al., 1991; Davis et al., 1986, 1987, 1990) (Figs. 11A-11B). A compilation of the MCS cross-sections is shown in Figure 12. Extensive studies of the deformation front region also have been conducted on the adjacent margin off Washington (e.g., Carson et al., 1974; Carson, 1977; Cochrane et al., 1988). The incoming 2.5to $3-\mathrm{km}$-thick sediment section consists of an upper $1.5-2 \mathrm{~km}$ of acoustically layered turbidite sediments overlying a section of more transparent sediments. The latter are interpreted to be pre-Pleistocene hemipelagic sediments deposited on the flanks of the Juan de Fuca Ridge (e.g., Hayes and Ewing, 1970; Davis and Hyndman, 1989). The upper part of the section was sampled to the south and to the north of the southern Vancouver Island margin by Deep Sea Drilling Project (DSDP) Leg 18 (Kulm, von Huene, et al., 1973, pp. 97-212). No significant bathymetric trench is present adjacent to the Cascadia accretionary prism. The oceanic crust dips gently landward toward the deformation front, with a corresponding thickening of the incoming sediment section. The maximum water depths are only about 2500 $\mathrm{m}$ as a consequence of the young age $(5-7 \mathrm{Ma})$ of the oceanic lithosphere at the deformation front and the thick sediment section.

At the deformation front, sediments of the Cascadia Basin are folded and faulted into elongate anticlinal ridges that stand as much as $700 \mathrm{~m}$ above the adjacent abyssal seafloor (Figs. 11A-11B and 12) (e.g., Davis and Hyndman, 1989). As seen in the acoustic images and bathymetric data (Figs. 11A-11B), individual ridges are typically $20-30 \mathrm{~km}$ in length, a few kilometers in width, and, in many cases, arcuate in plan. Although the structures generally strike parallel to the margin, locally the trends diverge by as much as $30^{\circ}$. The structure of the individual ridges is generally continuous along strike, with the amount of shortening decreasing from their centers toward their plunging ends (Rohr, 1987). Anticlines are commonly asymmetric with their steep sides facing seaward. In the northern of the Vancouver Island margin drilling areas (Sites 889 and 890; MCS lines 85-02, 89-07, and 89-08), a single frontal anticline has grown to a height of over $700 \mathrm{~m}$ above the basin floor. The internal structure of the anticline is not well imaged, but it is evident that it developed over a thrust ramp extending down to near the top of the oceanic crust. Subhorizontal basin sediments can be traced laterally some $4 \mathrm{~km}$ beneath the deformed hanging-wall material; evidence also exists for backtilting of weak reflectors in the hanging wall, landward of the anticline (Davis and Hyndman, 1989).

In the southern of the Vancouver Island drilling areas (Site 888; MCS lines 85-01, 89-03, 89-04, and 89-05), clearly imaged thrust faults penetrate the basin section. Three large offset faults are spaced about $5 \mathrm{~km}$ apart. Proto-thrusts with small offsets, in some cases not rising to the seafloor, and disturbed regions of the reflection sections also are evident seaward of the main faults. The main thrust faults clearly cut most of the section. They can be traced to about $2 \mathrm{~km}$ beneath the seafloor through offset of the stratigraphic reflection horizons. At greater depths the sediments lack clear internal reflectors and the location of the faults cannot be established with certainty; however, based on the geometry of the back-tilted beds of the hanging wall, Davis and Hyndman (1989) argued that they must penetrate to near the top of the oceanic crust. This fault penetration indicates that the present décollement is near the base of the sediment section and most of the incoming sediment is being scraped off the oceanic crust at the deformation front. There is a very strong reflector at that depth just landward of the deformation front on several seismic profiles, notably line 89-09 (Fig. 12) that also suggests that the décollement is located at the top of the oceanic crust. On the Oregon Margin, except in a few areas where the thrusts are seaward dipping and the detachment is at the base of the sediment section, the thrusts are landward dipping and the detachment is higher in the section (e.g., MacKay et al., 1992).

\section{Velocity and Porosity Variation Across the Prism}

A primary constraint on pore fluid expulsion associated with the sediment accretion is derived from landward change in porosity-depth relationships inferred from seismic velocity data (e.g., Bray and Karig, 1985; Bangs et al., 1990; Westbrook, 1991; Moore and Vrolijk, 1992). Detailed root-mean-square (RMS) and interval velocity cross-sections from Cascadia Basin across the accretion zone on lines 89-07 (nearly across Sites 889 and 890 ) and 89-04 (across basin reference Site 888) have been constructed by Yuan et al. (in press). Velocity analyses were conducted at 100 - to 200-m intervals. Starting with semblance velocity estimates, interactive adjustments of normal moveout (NMO) velocities were applied to flatten individual reflectors on CDP gathers. The velocities are well constrained for Cascadia Basin and for the frontal thrust zone where strong nearly horizontal stratigraphic reflectors are present. The velocities have lower accuracy landward as the sediments are progressively deformed, but quite good velocity resolution has still been achieved for about $20 \mathrm{~km}$ landward of the deformation front on line 89-07 (Figs. 13A-13B and 14). Landward from Cascadia Basin, the velocities first increase in the discrete thrust zone area, probably as a consequence of increasing horizontal tectonic stress (Yuan et al., in press). Further landward where the prism has thickened substantially, the velocities are much lower at any given depth than beneath Cascadia Basin. This landward velocity decrease and underconsolidation are inferred to be a consequence of horizontal shortening and vertical stretching of the porosity-depth profile. The tectonic thickening occurs faster than the loading and pore fluid expulsion can reestablish a normally consolidated section.

\section{THERMAL REGIME OF THE ACCRETIONARY PRISM}

\section{Accretionary Wedge Heat-flow Data}

A regional compilation of heat-flow data in the Juan de Fuca Plate region was prepared by Hyndman (1983), and Davis et al. (1990) reported heat-flow results across the Vancouver Island deformation front and lower continental slope. In the Davis et al. study (1990), heat-flow probe measurements were collected along two transects where a veneer of soft sediments permitted probe penetration. Considerable scatter is present, probably in part because of near-surface thermal conductivity variations that were not measured. Heat flow also was estimated from the sub-bottom depth of methane hydrate BSRs.

From these results, Davis et al. (1990) recognized a broad trend with heat flow decreasing monotonically landward across the continental margin from as high as $140 \mathrm{~mW} / \mathrm{m}^{2}$ (averaging $120 \mathrm{~mW} / \mathrm{m}^{2}$ ) in Cascadia Basin, to about $90 \mathrm{~mW} / \mathrm{m}^{2}$ over the lower continental slope, and to about $50 \mathrm{~mW} / \mathrm{m}^{2}$ over the continental shelf. The basin values agree well with the heat flow expected from the 6-Ma-age oceanic crust beneath Cascadia Basin after accounting for the effects of sedimentation. The decrease in heat flow landward was attributed to the effects of the subducting oceanic plate and the thickening of 
年

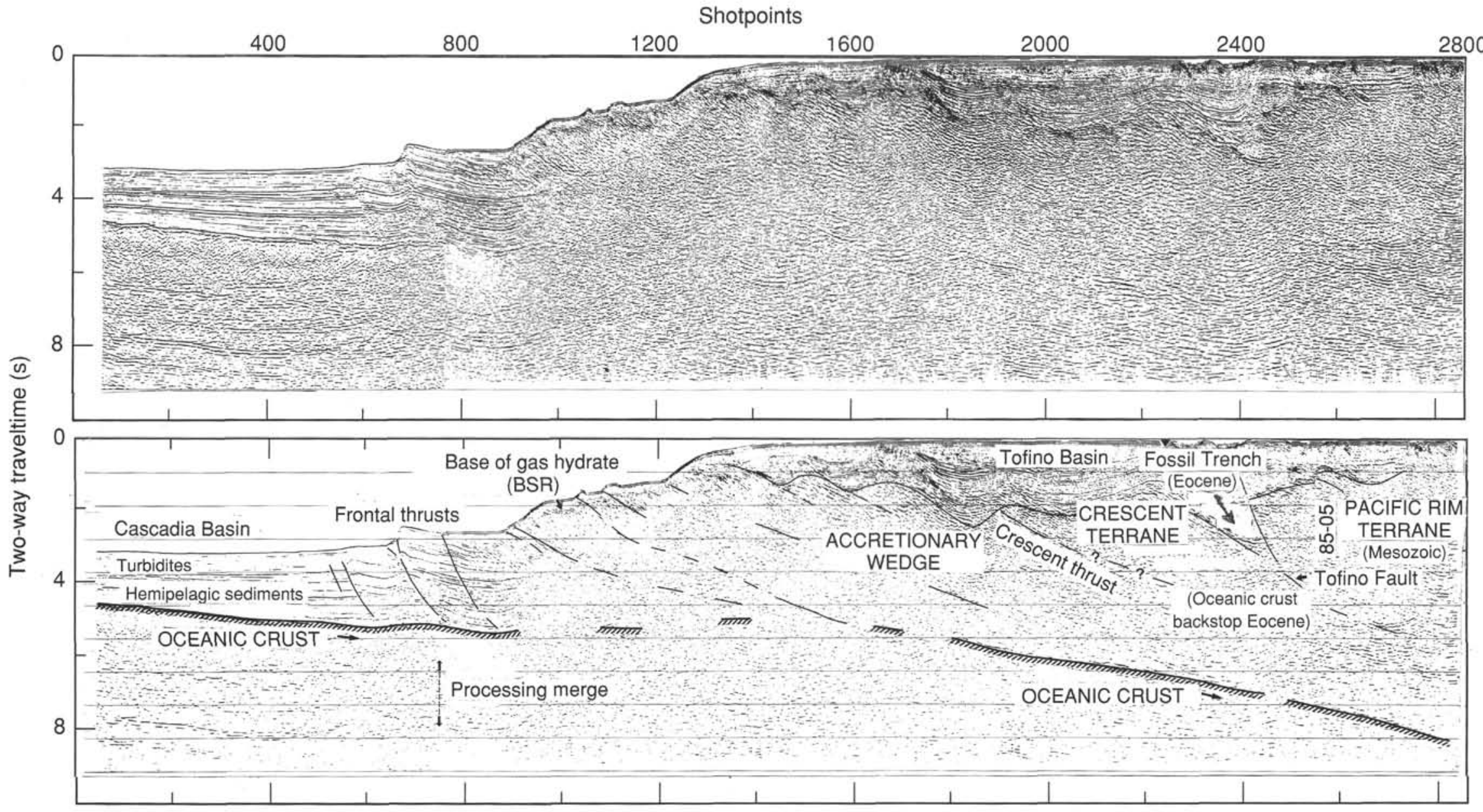

Figure 6. Multichannel seismic reflection line 85-01 section across the southern Vancouver Island margin to the coast (location on Figs. I and 9). The vertical exaggeration (VE) is approximately 3:1 for the upper sedimentary section and 1:1 for the high-velocity Crescent and Pacific Rim terranes at the landward end of the line. 


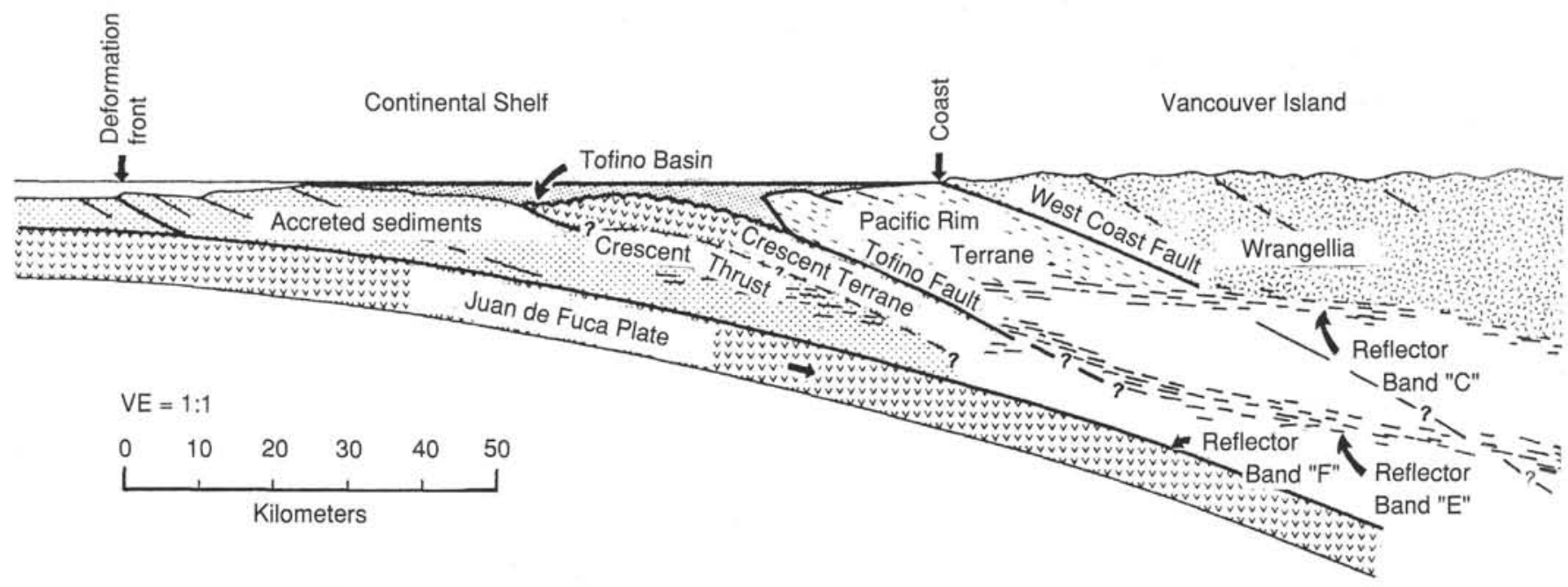

Figure 7. Offshore-onshore structural cross-section across the southern Vancouver Island margin (after Hyndman et al., 1990) (location on Fig. 1).

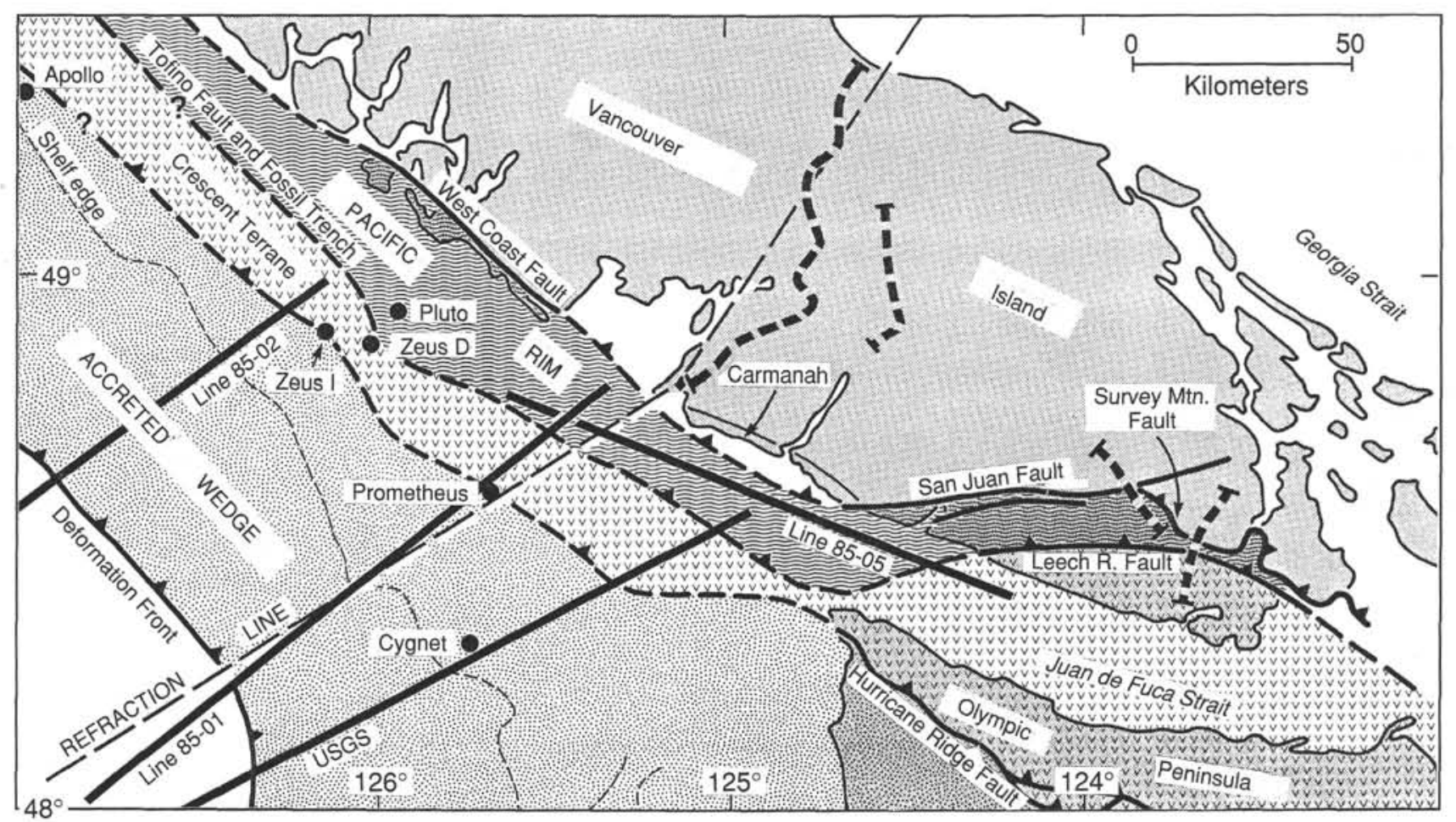

Figure 8. Plan view of southern Vancouver Island margin showing the positions of the Crescent and Pacific Rim terranes as they occur beneath the Tofino Basin sediments and outcrop on Vancouver Island and the Olympic Peninsula. The positions of several marine seismic lines are shown for reference. The locations of the LITHOPROBE land vibroseis seismic lines are shown as thick dashed lines.

the accretionary prism (see also Hyndman and Wang [1993] and following discussion).

Davis et al. (1990) also used the heat-flow data to constrain the nature of pore fluid expulsion from the accretionary prism. The lack of strong local thermal anomalies in the area of the deformation front suggested that only minor concentrations of fluid flux move up faults and other hydrologic conduits, and that most of the pore fluid from the consolidating accretionary prism must be expelled pervasively. On the lower slope, a systematic discrepancy was observed between the probe and BSR heat-flow determinations; heat flow at the seafloor was found to average $30 \%$ higher than that estimated over the upper
$250 \mathrm{~m}$ of the sediment section using the depth to the BSR. This discrepancy was attributed to advective heat transport from distributed vertical pore fluid flow. An expulsion rate of $25 \mathrm{~mm} / \mathrm{yr}$ was inferred. Recent estimates of the rates of fluid expulsion from simple mass-balance calculations and deformation modeling (LePichon et al., 1990; Hyndman and Davis, 1992; Wang et al., 1993; Hyndman et al., in press) indicate, however, that a reasonable upper limit for the magnitude of regional flux is $1-2 \mathrm{~mm} / \mathrm{yr}$, an order of magnitude too small to account for the discrepancy.

The cause of the discrepancy between the seafloor and BSR values is as yet unresolved; it may lie with errors in either of the methods 


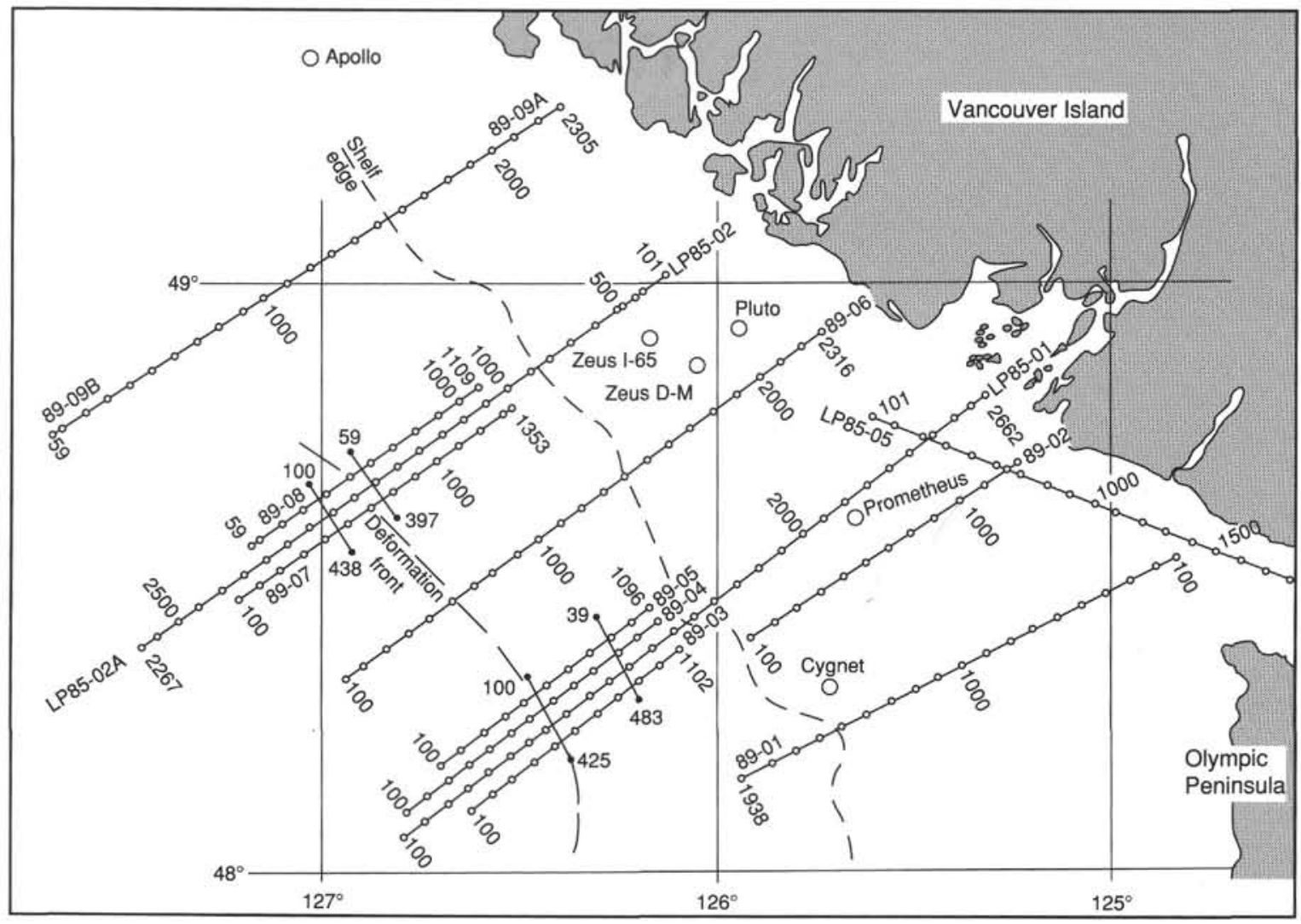

Figure 9. Location map showing the multichannel seismic lines on the southern Vancouver Island margin. Every 100 shotpoints are marked by an open dot. The deformation front sections are shown in Figure 12 and portions of lines 89-04, 89-08, and 89-10 are shown in Figure 10.

of determining heat flow. Numerous investigators have used the subbottom depth to methane-hydrate BSRs to estimate heat flow (e.g., Yamano et al., 1982; Davis et al., 1990; Ferguson et al., 1993; Hyndman et al., in press). Although general agreement has been found between seafloor probe and BSR heat-flow data, no entirely adequate comparison and calibration of the latter has been possible. The overall BSR heat-flow uncertainty is estimated to be about $20 \%$ (see discussion below). Errors in seafloor probe heat-flow determinations are typically much smaller than the errors in BSR heat flow; however, because of difficulties with probe penetration and the small number of successful in-situ thermal conductivity measurements, the uncertainty in the measurements presented by Davis et al. (1990) was unusually large.

\section{New Seafloor Probe Heat-flow Data over Sites 889 and 890}

To improve the seafloor heat flow accuracy in the vicinity of Sites 889 and 890, 10 new measurements were attempted in 1992 along MCS line 89-08 (E.E. Davis, unpubl. data, 1993). As in the case of the previous measurements, full penetration of the probe $(3.5 \mathrm{~m}$ in length) was never achieved, and probe tilts were often large. Results are shown in Figure 15 for those measurements where the tilt was less than $7^{\circ}$ and at least 5 thermistors (of 11) were in the sediment. The average sediment thermal conductivity at individual penetrations ranged from 1.04 to $1.19 \mathrm{~W} /(\mathrm{m} \cdot \mathrm{K})$, which brackets the average of $1.14 \mathrm{~W} /(\mathrm{m} \cdot \mathrm{K})$ for four values obtained previously in the vicinity. Values at discrete depths reached more than $1.5 \mathrm{~W} /(\mathrm{m} \cdot \mathrm{K})$, indicating the presence of sandy layers that possibly contained carbonate. Heatflow measurements ranged from 82 to $95 \mathrm{~mW} / \mathrm{m}^{2}$ and agreed well with the nearby previous measurements, which ranged from 88 to 107 $\mathrm{mW} / \mathrm{m}^{2}$ (Fig. 15). Thus, the discrepancy between probe values and the heat flow derived from the BSR data remains unexplained.

\section{New BSR Heat-flow Data}

From the variations in BSR depths, Hyndman et al. (in press) obtained a broad distribution of new heat-flow data along all of the available MCS; the extensive distribution of the BSR is shown in Figure 16. The BSR is recognized to mark the base of the stability field for gas hydrate (see section below). Because its depth is controlled primarily by temperature it may be used to estimate heat flow (Yamano et al., 1982; Davis et al., 1990; Ferguson et al., 1993). Heatflow estimates require determinations of (1) the reflection time from the seafloor to the BSR; (2) the average seismic velocity to the BSR, to convert reflection times to depths (3) the seafloor temperature from oceanographic or heat probe measurements; (4) the melting or dissociation temperature at the BSR from the pressure-temperature (P-T) conditions for hydrate stability given by laboratory data; with the seafloor temperature, this gives the vertical temperature difference and gradient; and, (5) the average thermal conductivity from the seafloor to the BSR from velocity and other data to obtain the heat flow. Probably the largest uncertainties come from (1) assumptions about the applicable stability field (i.e., appropriate fluid and gas composition; e.g., Hyndman et al., 1992), which introduces a heat-flow uncertainty of $10 \%-20 \%$; and (2) the thermal conductivity, which can only be determined from velocity and seafloor data to an accuracy of $10 \%-20 \%$ (e.g., Hyndman et al., in press). Conductivity also may have substantial lateral variability. The overall heat-flow uncertainty is estimated to be about $\pm 20 \%$; however, much of this error is probably systematic and nearly constant for the region. The estimated relative uncertainty over the region is $\pm 10 \%$, which corresponds well to the scatter of the heat-flow points along the individual profiles. The BSR heat-flow estimates along the three seismic lines near the slope drill site (Sites 889 and 890 ) are compared to the probe data and the model heat flow in Figure 17. 

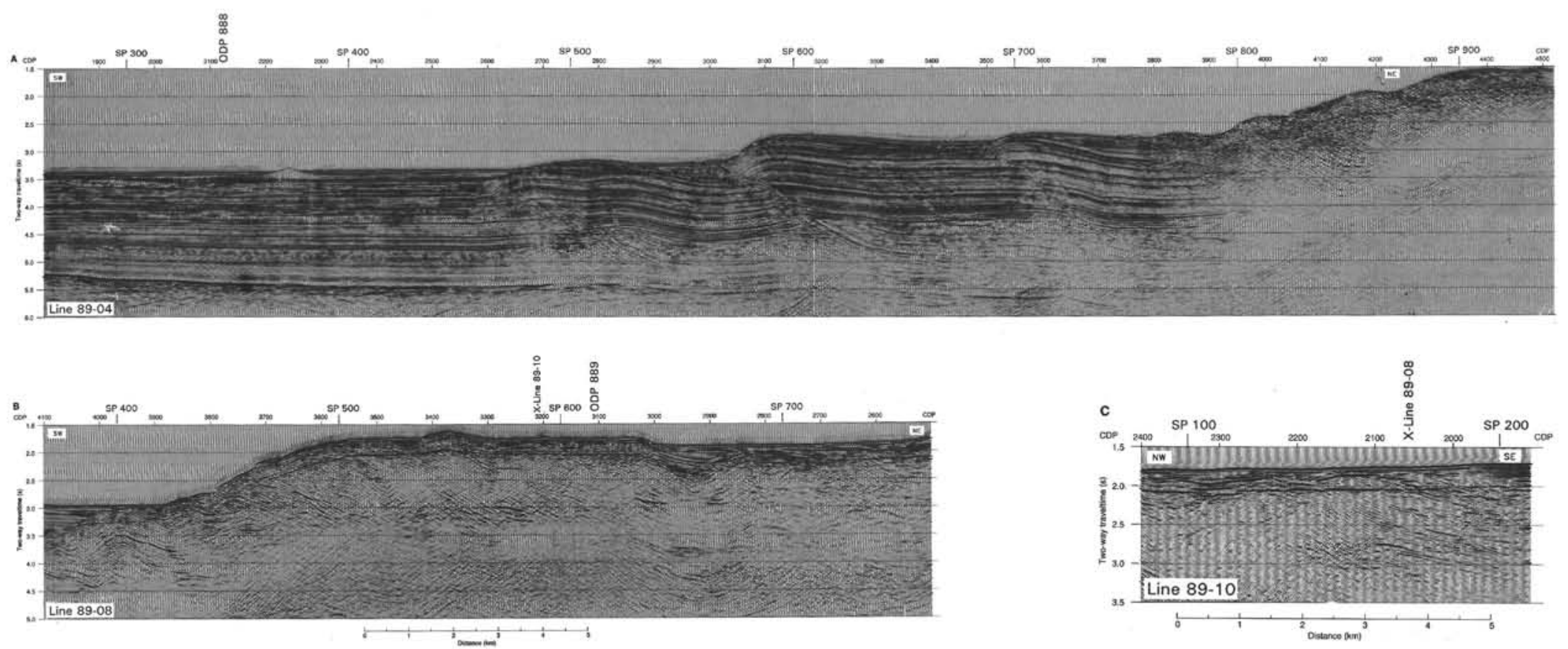

Figure 10. Multichannel seismic sections along lines 89-04 (A), 89-08 (B), and 89-10 (C) across the Leg 146 drill sites. For greater detail, see enlarged versions in back pocket. 

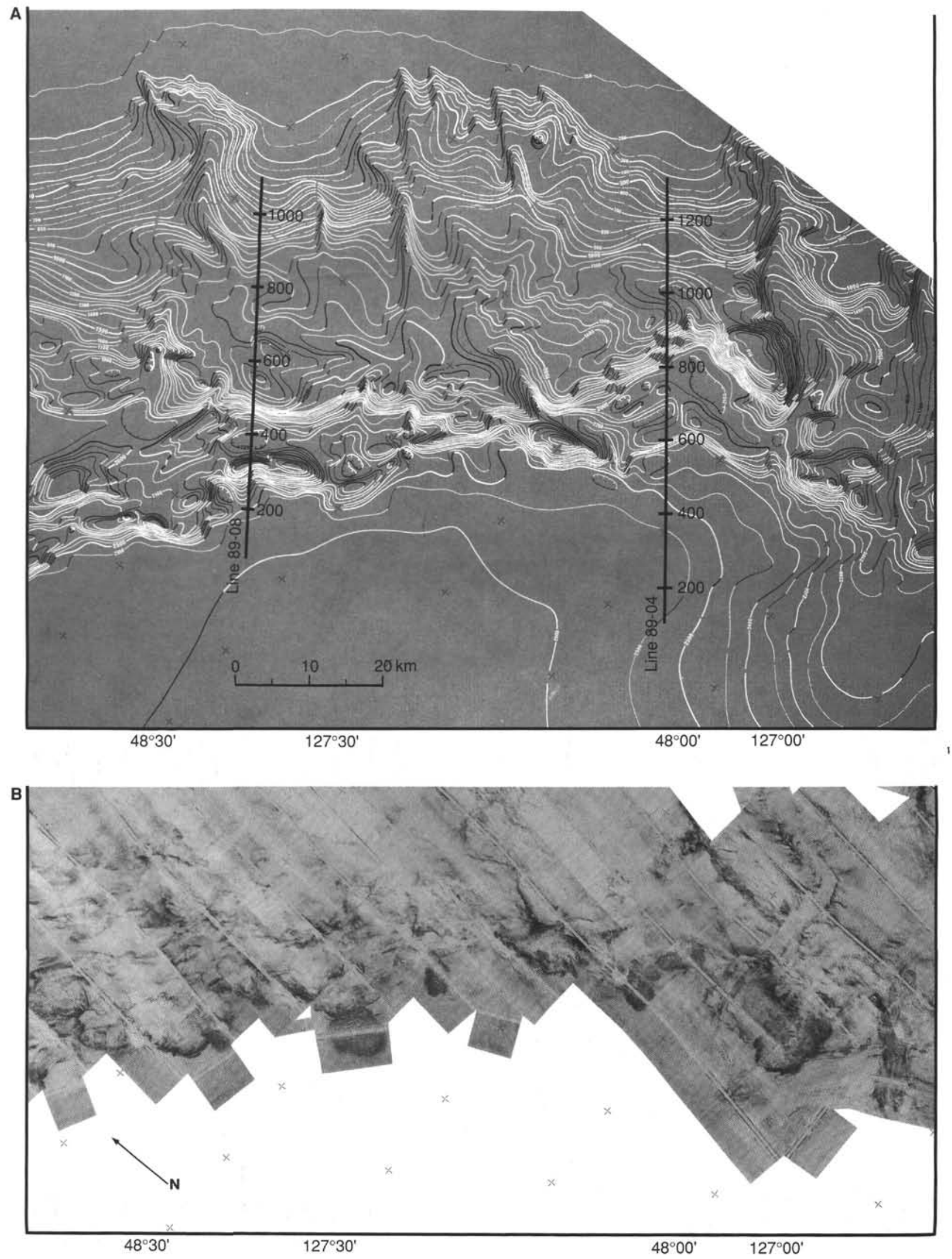

Figure 11. A. Detailed bathymetry of the southern Vancouver Island deformation front region. B. SeaMARC II acoustic imagery mosaic of the southern Vancouver Island deformation front region. For greater detail, see enlarged versions in back pocket. 

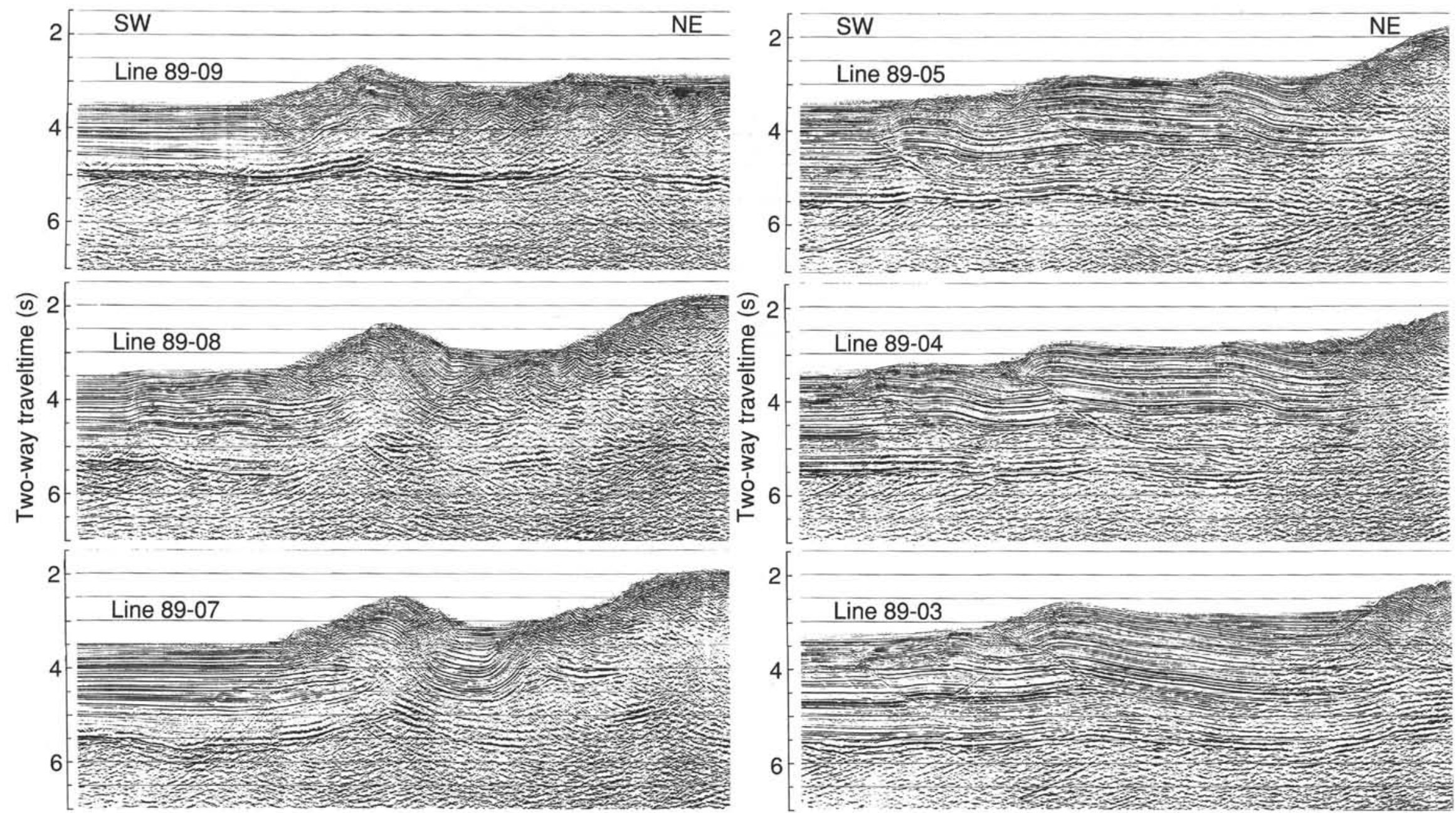

$$
0
$$$$
5
$$

Distance (km)

10

Figure 12. Compilation of multichannel seismic sections across the deformation front area off southern Vancouver Island (locations in Fig. 9). 

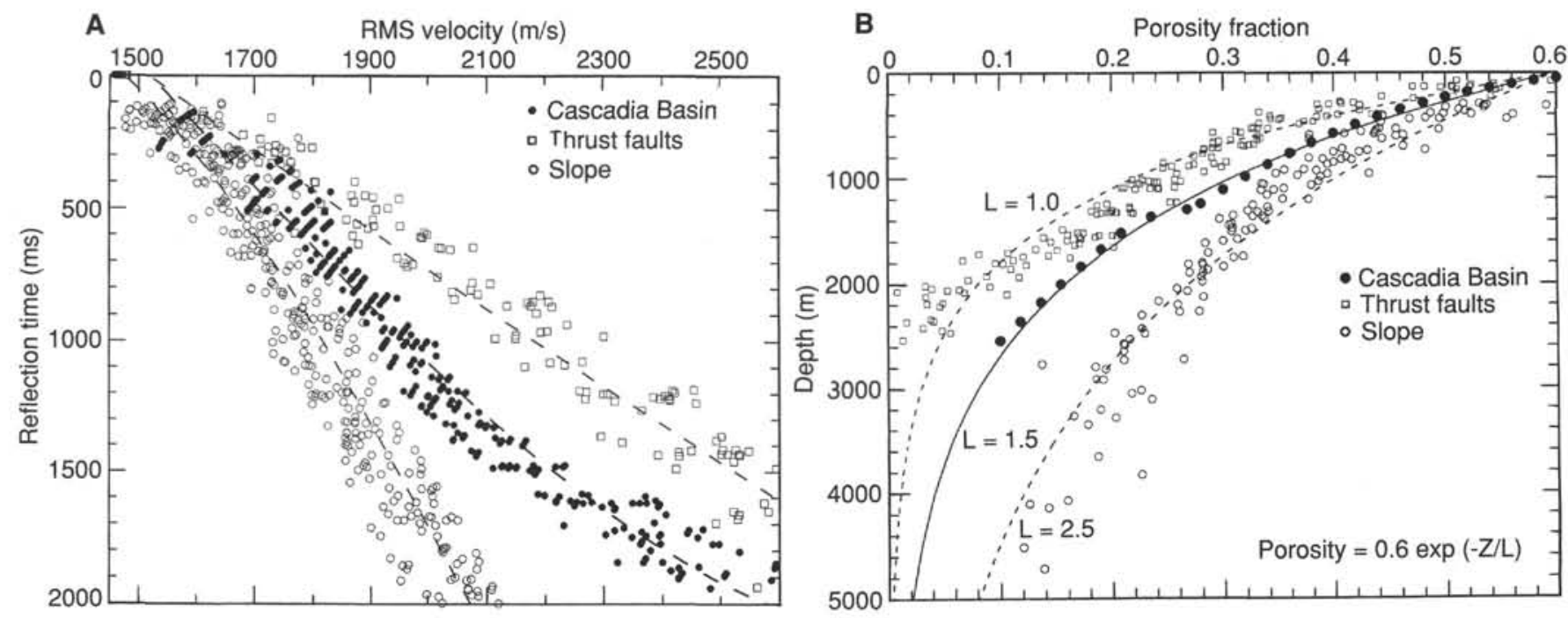

Figure 13. A. Root-mean-square (RMS) velocity vs. sub-bottom depth (water column removed) for the Cascadia Basin, high-velocity thrust zone (landward of reference Site 888) and low-velocity mid-slope region (region of Sites 889 and 890 ). B. Porosity vs. depth functions for the Cascadia Basin, high-velocity thrust zone (landward of reference Site 888) and low-velocity mid-slope region (region of Sites 889 and 890). The solid dots for the basin define regression lines through the data for the upper turbidite and lower "hemipelagic" sections.

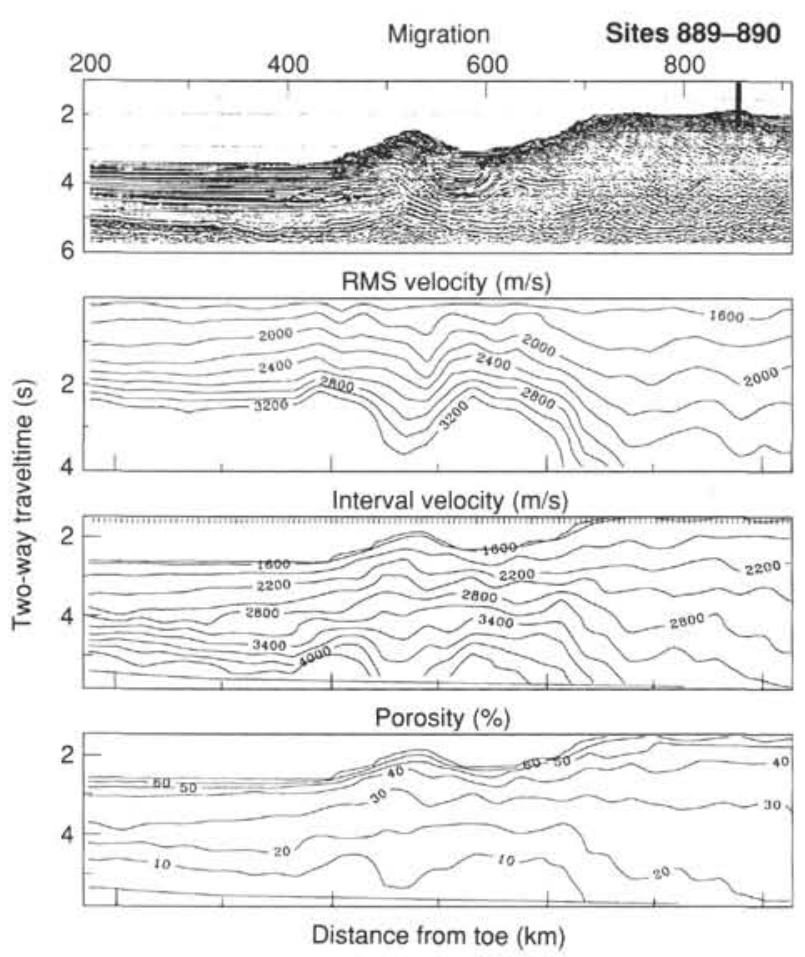

Figure 14. Seismic, root-mean-square (RMS) velocity below the seafloor, interval velocity, and porosity cross-sections along seismic line 89-07, which passes close to Sites 889 and 890 . The small vertical ticks at the top of the panel showing interval velocity mark the locations of the velocity analyses. The solid vertical line on the seismic section shows the projected location of Sites 889 and 890.

\section{Large-scale Subduction Zone Thermal Regime}

Thermal models using surface heat flow as a boundary condition provide one of the most important means for understanding sediment accretion and fluid expulsion processes. To examine the effects of sediment thickening and fluid expulsion in the accretionary prism, the

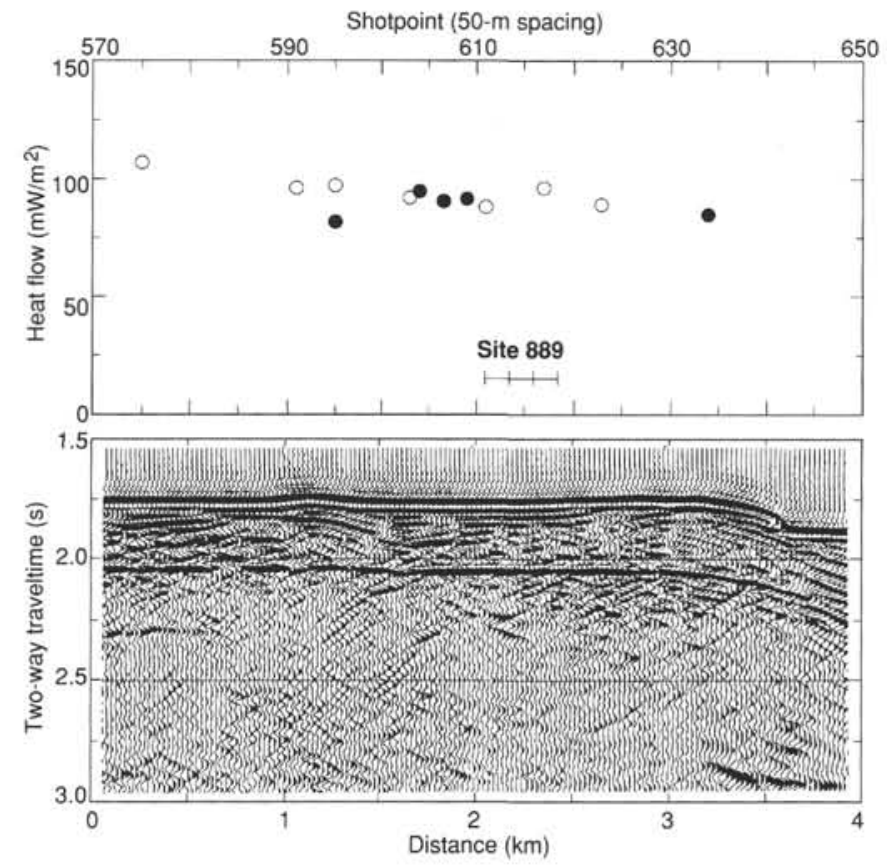

Figure 15. Profile of heat probe measurements across Sites 889 and 890 . The solid dots are new data obtained in 1992 along line 89-08, which crosses Sites 889 and 890; the open dots are from Davis et al. (1990) along parallel line 85-02. The latter are projected onto line 89-08 about $4 \mathrm{~km}$ away.

larger scale subduction thermal regime must be subtracted. The largescale thermal regime of the margin is dominated by the effects of underthrusting of the oceanic lithosphere. Although the oceanic lithosphere is young, 5-7 Ma at the deformation front, and the offshore heat flow is high, the incoming plate provides a substantial heat sink beneath the margin. The result is low heat flow in the forearc area, decreasing landward to about $35 \mathrm{~mW} / \mathrm{m}^{2}$. An abrupt increase to very high heat flow occurs just seaward of the volcanic arc (Fig. 3) (Lewis et al., 1988, 1991). The heat flow on Vancouver Island is well defined by numerous borehole measurements and the heat flow on the continental shelf is 


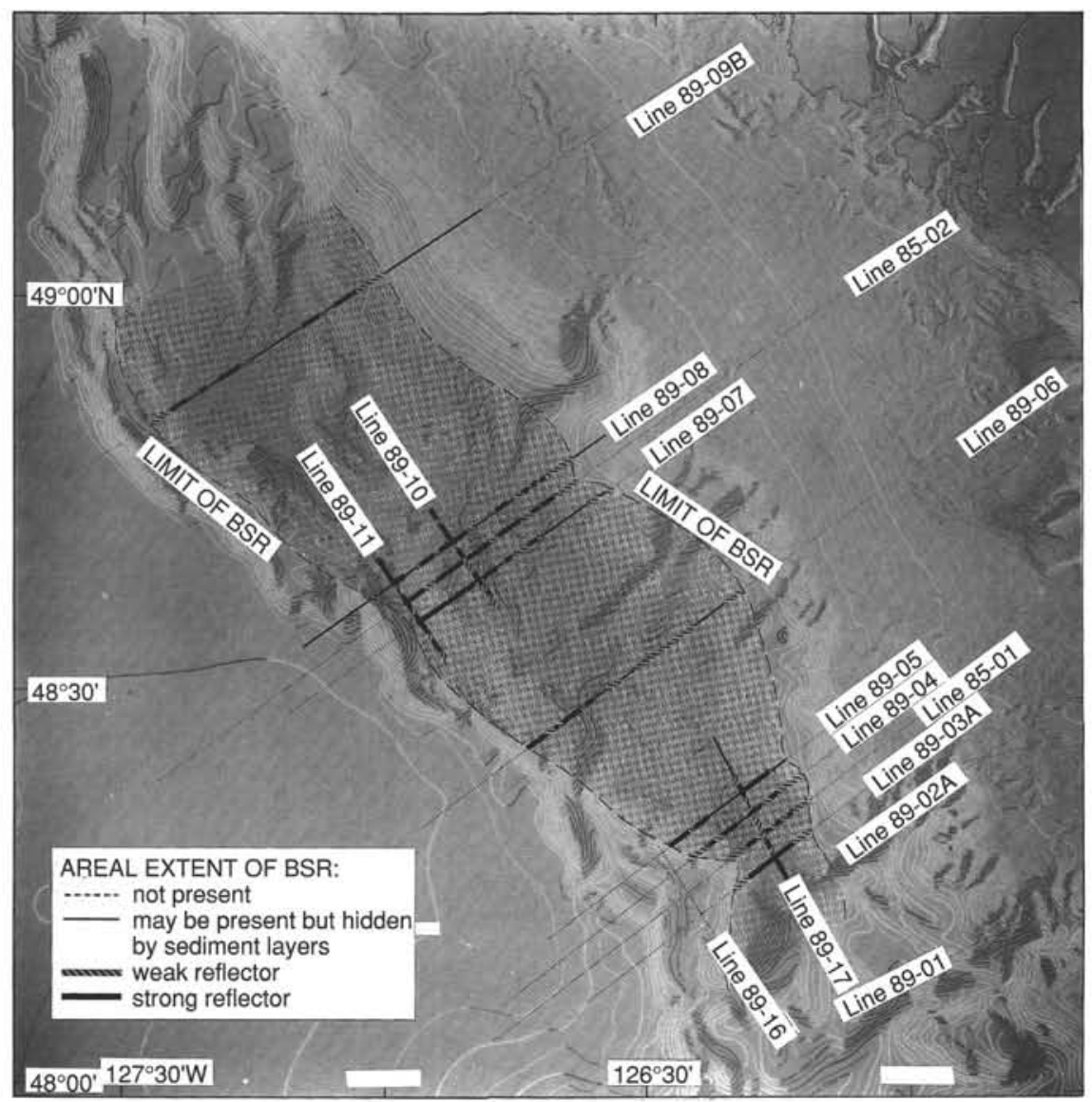

Figure 16. Distribution of hydrate BSRs on the southern Vancouver Island margin. The thick lines mark where the BSR is clear, the diagonal lines mark the location of weak BSRs, and the thin solid lines mark where BSRs are not evident but weak BSRs would be obscured in the data. The shaded area delineates the general region where BSRs are observed.

constrained, with lower accuracy, by data from hydrocarbon exploration wells. Offshore in Cascadia Basin, extensive ocean probe data agree with the predicted heat flow for the age of the ocean crust after correction for the effect of sedimentation (Davis et al., 1990; Hyndman and Wang, 1993) (see Fig. 18). A numerical model for temperatures beneath the margin, excluding the transient effects of the accretionary prism sediment thickening and fluid expulsion, has been presented by Hyndman and Wang (1993). Their model provides a deep temperature and heat-flow reference upon which thermal effects of the accretionary prism processes are superimposed. The Cascadia Margin is unusually hot as a consequence of the very young age of the incoming oceanic plate and the thick insulating sediment section covering it; the temperature at the top of the oceanic crust at the deformation front is about $250^{\circ} \mathrm{C}$. Although the heat flow and thus the vertical temperature gradient decrease landward, the temperature at the base of the thick accretionary prism near the coast of Vancouver Island exceeds $400^{\circ} \mathrm{C}$. Hyndman and Wang (1993) have argued that the high temperatures result in an unusually narrow locked zone on the subduction thrust on which large earthquakes may occur (Fig. 18). Earthquakes cannot initiate where the temperature exceeds about $350^{\circ} \mathrm{C}$.

\section{Thermal Effect of Sediment Accretion and Fluid Expulsion}

The advective thermal effects of sediment accretion, thickening, and fluid expulsion have been estimated from the ratio of the BSR heat flow to the predicted heat flow from the regional model of Hyndman and Wang (1993). The regional model, which assumes a steady-state conductive thermal regime above the top of the oceanic crust (transient within the oceanic lithosphere), gives excellent agreement with the heat-flow data landward of the accretion zone on Vancouver Island and seaward in the Cascadia Basin (e.g., Fig. 18). Figure 19 shows the difference between the BSR heat flow and that from the regional model for seven seismic lines across the southern Vancouver Island margin (northern group of three and southern group of four lines in Fig. 9). The regional model heat flow depends upon the crustal age at the deformation front for each seismic line (5-7 Ma). This heat-flow difference is taken to be a result of the thermal effects of sediment thickening and fluid expulsion that are not included in the regional model. Temperatures in the underthrusting oceanic lithosphere are not strictly independent of transient processes in the accretionary prism; however, the regional model that assumes that they are independent is probably a reasonable approximation. A consistent pattern can be discerned in the heat-flow difference, although considerable scatter is present. The BSR heat flow agrees with that of the steady-state model near the deformation front and again about $30 \mathrm{~km}$ landward of the deformation front on the upper continental slope (Fig. 18). In the intervening band, centered about $15 \mathrm{~km}$ landward of the main frontal thrust or fold, the BSR heat flow is $70 \%-80 \%$ of the conductive upper plate model. The average difference, smoothed over local folds and faults on individual lines, is interpreted to be the result of the combined thermal effect of sediment thickening and fluid expulsion. The other important constraint on sediment consolidation and fluid expulsion, the inferred variation in sediment porosity landward in the prism, is discussed above. 

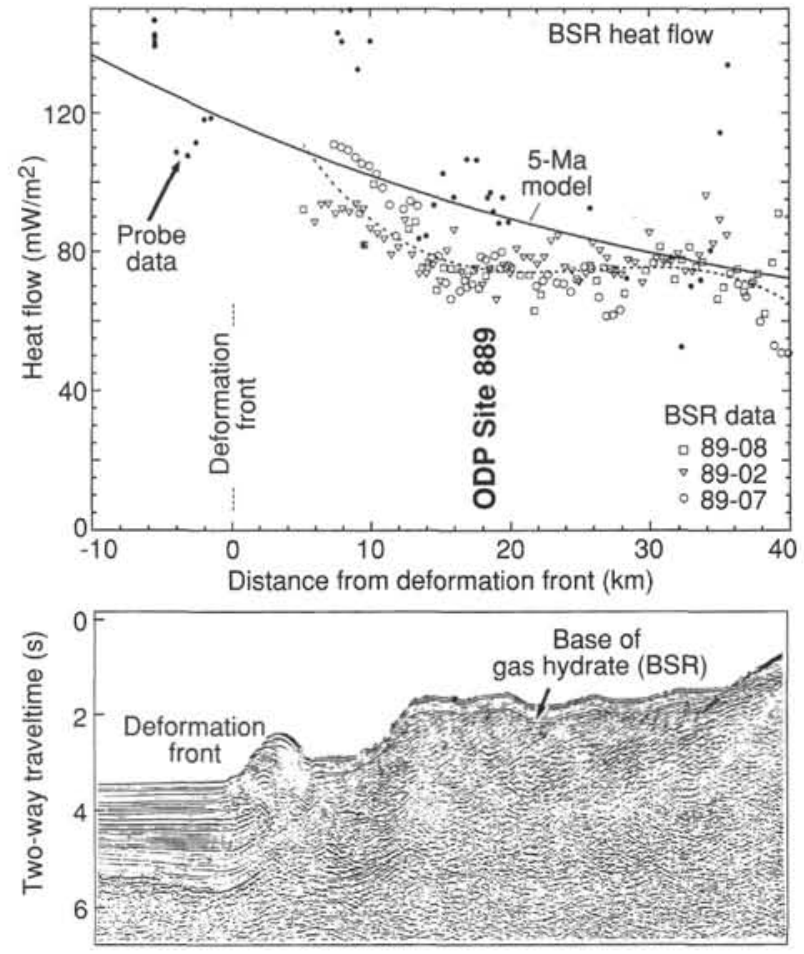

Figure 17. Heat-flow data across the southern Vancouver Island margin through Sites 889 and 890 from BSR depths (and earlier probe measurements). The predicted, large-scale, heat-flow model ignoring accretionary prism processes is shown for comparison (solid line). The dashed line is smooth average fit to the BSR data. The seismic section is line 85-02.

\section{Sediment Thickening and Fluid Expulsion Models}

The sediment accretion process can be represented by a combination of two processes: simple bulk shortening and vertical thickening of the section, and thrust faulting that emplaces high-porosity surface sediment to greater depths. In either process, the rate of porosity reduction with depth is reduced but the average porosity of the sediment section initially does not change. Thus, thickening results in a greatly underconsolidated section. Subsequent to thickening, the original equilibrium porosity-depth profile of the basin section tends to be reestablished through consolidation and pore fluid expulsion. For this reestablished, approximately normally consolidated profile, the thickened section has a lower average porosity in comparison with the incoming basin section. The total porosity reduction corresponds to the amount of fluid expelled. Self-similar thickening models have been given by Shi and Wang (1988), LePichon et al. (1990), Bekins and Dreiss (1992), and Wang et al. (1993). Their models ignore the effects of local faulting and folding. Hyndman et al. (in press) have applied the model of Wang et al. (1993) to the Vancouver Island margin, with constraints provided by the pattern of surface heat flow and of porosity variation (from velocity) across the seaward portion of the prism; the effects of overconsolidation produced by horizontal tectonic stress have been ignored.

Two processes in the accretionary prism affect the surface heat flow. Thickening of the prism expands the vertical isotherm spacing faster than the rate of conductive reequilibration. This rapid thickening reduces the vertical temperature gradient nearly uniformly throughout the thickness of the prism. Consolidation and fluid expulsion introduces advective heat transport. In the simple models this transport is assumed to be nearly vertical; it reduces the vertical heat flow at depth and increases it near the surface. The model of Hyndman et al. (in press), constrained by the porosity distribution estimated from the velocity data, predicts a maximum reduction of heat flow from the sediment thickening to occur $10-20 \mathrm{~km}$ landward from the deformation front. This model result corresponds well to the pattern obtained from the heat-flow data. Further landward, the surface heat flow is inferred to be increased by upward fluid expulsion and the effects of sediment thickening and fluid expulsion nearly cancel (Fig. 19).

An important inference from the seismic velocity data and from the models is that the sediments in the frontal portion of the accretionary prism are underconsolidated and therefore high pore pressure must exist in the accretion zone (e.g., Westbrook, 1991). The excess pore pressure also may be obtained from the pore-fluid expulsion estimated from the heat-flow data; the pore pressure required to drive the fluid expulsion and thus the pore pressure depends on the permeability distribution (e.g., Hyndman et al., in press).

\section{DEEP-SEA GAS HYDRATE}

On some continental margins, particularly those with large accretionary prisms, a clear reflector is present that parallels the seafloor at sub-bottom depths of 200-600 m (bottom-simulating reflector or "BSR"). The BSR is thought to be associated with the base of the stability field of gas hydrate. Hydrates are solid icelike substances consisting of water molecule cages stabilized by enclosed gas molecules (e.g., Sloan, 1990). In the samples previously recovered by DSDP/ODP, the gas has been almost entirely methane (Kvenvolden and McDonald, 1985; Shipley and Didyk, 1981; McIver, 1974), and in most deep-sea occurrences the gas is probably methane. Hydrates contain large concentrations of gas, up to $7.6 \mathrm{~mol} / \mathrm{L}$ or a methane to water ratio of about 164:1 at STP for pure methane hydrate when dissociated. Natural hydrates are expected to have close to these concentrations. Except for the high dissociation or melting temperature at deep-sea pressures, most of the properties of hydrate such as density and seismic velocity are similar to those of normal ice. Interest in hydrates has arisen because of their potential as a clean fuel resource and because they may play a role in the control of global climate. Deep-sea hydrate layers are estimated to contain a very large amount of methane. Their energy potential may exceed known land hydrocarbon resources (e.g., Kvenvolden, 1988; MacDonald, 1990). Methane is a very effective greenhouse gas, and its release from hydrate could result in abrupt global warming (e.g., Nisbet, 1990). Deep-sea hydrates are inferred to form mainly from biogenically generated methane, the product of low-temperature anaerobic bacterial action on the organic material in the sediments (methanogenesis) (e.g., Claypool and Kaplan, 1974).

\section{Hydrate Pressure-Temperature Stability}

The pressure-temperature (P-T) stability field of hydrate (i.e., the freezing temperature for a particular pressure) depends on the composition of the enclosed gas and on the water salinity. The dissociation temperature is increased by the presence of higher hydrocarbons and $\mathrm{CO}_{2}$, and decreased by higher salinity. Figure 20 illustrates the stability field based on laboratory data (tabulated in Sloan, 1990). The boundary for methane and pure water is well known, but that for methane and seawater-salinity fluid is not. The best estimate probably comes from equation-of-state calculations for artificial seawater by Englezos and Bishnoi (1988), which yield a temperature about $1^{\circ}$ colder than for pure water hydrate at the pressure of the Vancouver Island margin mid-slope BSR (Fig. 20). This difference is less than some previous estimates for the difference of $2^{\circ}-3^{\circ} \mathrm{C}$, based on limited laboratory data on the effect of $\mathrm{NaCl}$. The temperature at the $\mathrm{BSR}$ may depend on whether hydrate is forming or melting, because salt is largely excluded from the hydrate structure as in the case of normal ice. In-situ estimates of the temperature and pressure at the BSR with uncertainties of $2^{\circ}-3^{\circ} \mathrm{C}$ for three sites (Nankai [Japan], Peru Margin, and Blake- 

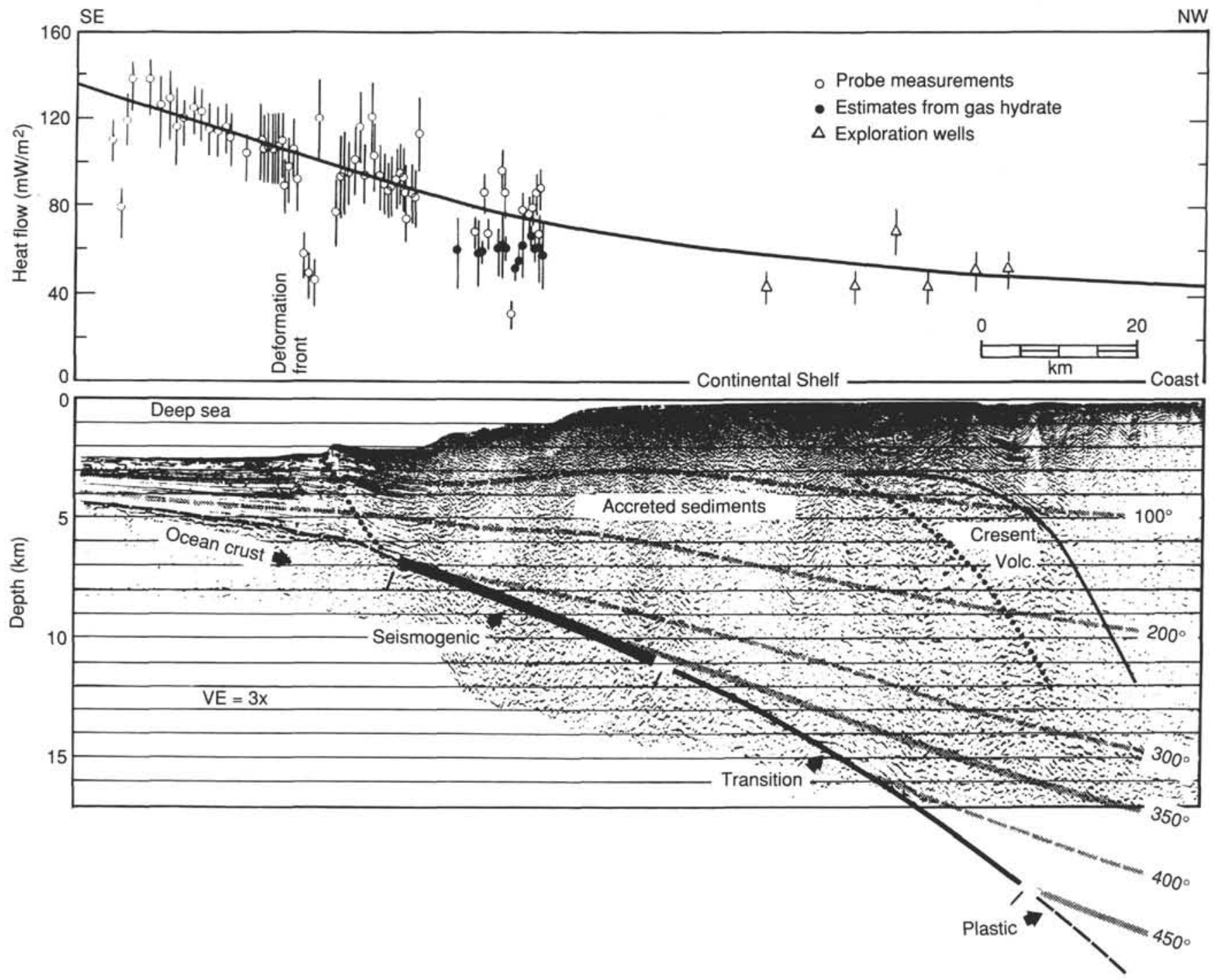

Figure 18. Heat-flow data and model temperatures in the southern Vancouver Island margin accretionary prism ignoring the effects of prism processes; the megathrust seismogenic (locked) zone, limited to $350^{\circ} \mathrm{C}$. and the transition zone, to $450^{\circ} \mathrm{C}$, are illustrated (after Hyndman and Wang, 1993).

Bahama), were presented by Hyndman et al. (1992). Their data best fit the pure methane and pure water stability field (Fig. 20) but the uncertainties encompass the estimated seawater-methane field. Accurate calibration of the BSR temperature is important for understanding the chemistry of the hydrate and its mode of formation, and for the use of the BSR depth to obtain heat flow; such calibration is an important objective of the Vancouver Island margin BSR drilling.

\section{Mechanism of Hydrate Formation}

The mechanism for formation of deep-sea hydrate has recently been the subject of considerable debate. The simplest model has the formation of hydrate from methane generated locally at depths where the P-T conditions are within the stability field, perhaps with some upward migration of free gas from below. However, Hyndman and Davis (1992) argued that sufficient methane cannot be generated locally to produce the amounts of hydrate inferred from seismic and DSDP/ODP borehole data. They suggested that the hydrate layers above BSRs are formed through removal of methane from upward-moving pore fluids as they pass into the stability field (Fig. 21). In this model, the required methane may be generated throughout a thick sediment section below the BSR. The model accounts for the evidence that BSRs occur only in certain environments. Strong upward fluid expulsion occurs as a result of tectonic thickening and loading in subduction zone accretionary prisms, and, in a few areas, where rapid deposition results in initial underconsolidation. In these areas BSRs are common. This mechanism requires diffuse fluid expulsion which is consistent with the evidence that BSRs are largely restricted to sand-dominated accretionary prisms; they do not generally occur in those composed of fine grained muds through which fluid expulsion is expected to be strongly channeled (for example, the sandy southern Barbados accretionary prism as compared with the mud-dominated northern portion of the prism; e.g., Bangs et al., 1990). Channeled fluid expulsion may produce hydrate but not in a continuous seismically reflective layer.

Several predictions about the nature of the hydrate associated with BSRs also follow from the fluid expulsion model that can be tested by drilling:

1. The hydrate should be concentrated just above the BSR with decreasing amounts upward (from downhole log velocity and core pore-fluid salinity and methane content data); results from drilling off Middle America that reached close to but did not penetrate the BSR 


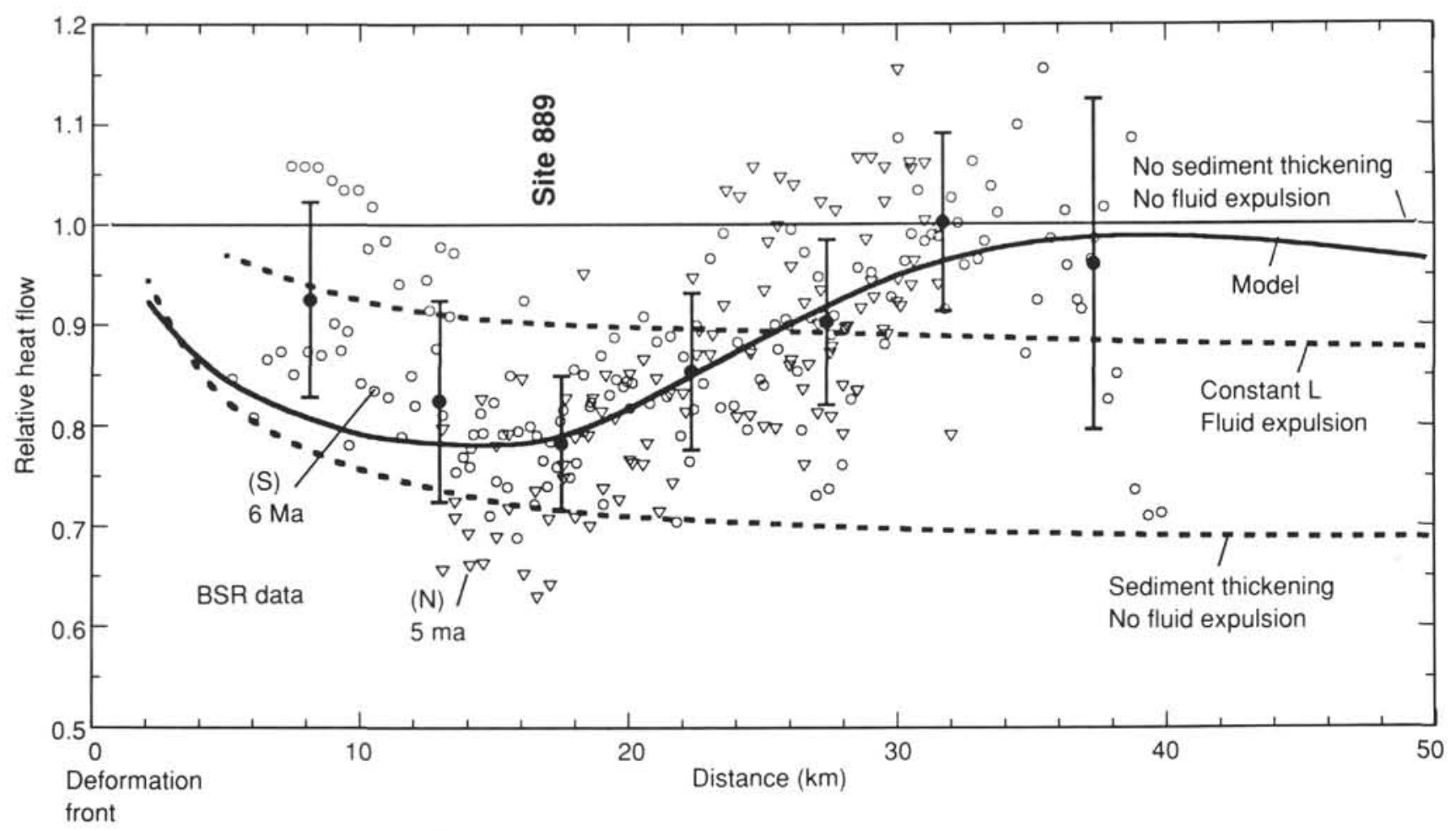

Figure 19. A compilation of the difference between BSR heat flow and the large-scale model profile from seven seismic lines across the southern Vancouver Island margin. The open circles (S) are for the southern group of four profiles, the triangles $(\mathrm{N})$ are for the northern group of three profiles. The vertical bars are the heat-flow averages and standard deviations for 5-km intervals. The model heat-flow profile (solid line) (Hyndman et al., in press) that allows for the transient effects of sediment thickening and fluid expulsion is shown for comparison, along with the heat flow predicted for a porosity-depth function that does not change landward (constant L) and for simple thickening and vertical stretching of the porosity-depth function (no fluid expulsion).

suggest this distribution from core pore fluid salinity profiles (discussion in Hyndman and Davis, 1992).

2. The amount of methane in core samples should be a maximum just above the BSR (from hydrate that dissociated upon recovery of the core) and lower below the BSR (present only as dissolved methane and limited amounts of free gas).

In the simple model in which methane is formed locally, hydrate should be distributed evenly from the BSR to near the seafloor, and the methane concentrations should be about the same above and below the BSR. The simple local methane model may be complicated by the upward migration of free gas from below.

An important complication to models of hydrate formation is the effect of recent upward (or less commonly, downward) movement of the base of the stability field from (1) slope sediment deposition; the base of the stability field must rise in response to changing temperature; (2) uplift and pressure reduction from prism tectonic thickening landward; the base of the stability field must rise to correspond to the lower dissociation temperature for the lower pressure; and (3) an increase in bottom-water temperature since the Pleistocene (G.K. Westbrook, pers. comm., 1992). In all of these cases of upward movement, the lower portion of the hydrate layer must dissociate as the stability field rises. The methane will be released as free gas, which should rise to reform hydrate at a higher level, either by upward diffusion or carried by continued upward fluid expulsion. Thus, the concentration of methane beneath the BSR is expected to increase upward toward the BSR. This zone refining-like process should produce diagnostic isotope and geochemical signatures, although they may be complex. Downward movement of the base of the stability field is probably less common, but it could occur from sediment erosion or from the landward decrease in heat flow as sediments are carried into the accretionary prism.

\section{Bottom-simulating Reflectors and Hydrate}

The primary source of regional information on deep-sea hydrate is from the seismic reflection data (e.g., Shipley et al., 1979; Shipley and Didyk, 1981; Minshull and White, 1989; Miller et al., 1991; Hyndman and Spence, 1992; Holbrook and Paull, 1992) (Fig. 22). The characteristic BSR allows the regional distribution of hydrate to be mapped, and its analysis can provide semiquantitative information on the amount and distribution of hydrate and underlying free gas. Seismic analyses have included (1) determination of BSR reflection coefficients, (2) modeling of the vertical-incidence reflection waveforms, (3) multichannel velocity-depth analysis, (4) analysis and modeling of amplitude and waveform vs. offset; amplitude vs. offset (AVO) is especially sensitive to the presence of free gas, and (5) full waveform modeling. The Cascadia Margin has an advantage over many other accretionary prisms in that the shallow water depths allow large-angle offsets for AVO, velocity, and full waveform analyses. The key questions to be resolved are the amount and distribution of hydrate above the BSR and of free gas below the BSR.

The BSR reflection coefficient can be obtained by comparing the amplitudes of the seafloor and BSR reflections; the seafloor reflection coefficient, in turn, can be obtained either from estimates of the velocity and density of the seafloor sediments or from the relative amplitude of the primary seafloor reflection and its multiple (Warner, 1990). Seafloor reflection coefficients are commonly $30 \%$ on the northern Cascadia Margin. The stronger BSRs have amplitudes of $30 \%-50 \%$ of the seafloor yielding reflection coefficients of $10 \%-$ $15 \%$ (Hyndman and Spence, 1992). This is similar to values found in other areas of strong BSRs. The average BSR reflection coefficient and the reverse polarity of the reflection imply a decrease in seismic impedance of $20 \%-30 \%$. This contrast can be matched by several models with and without a gas layer. Miller et al. (1991) showed that 


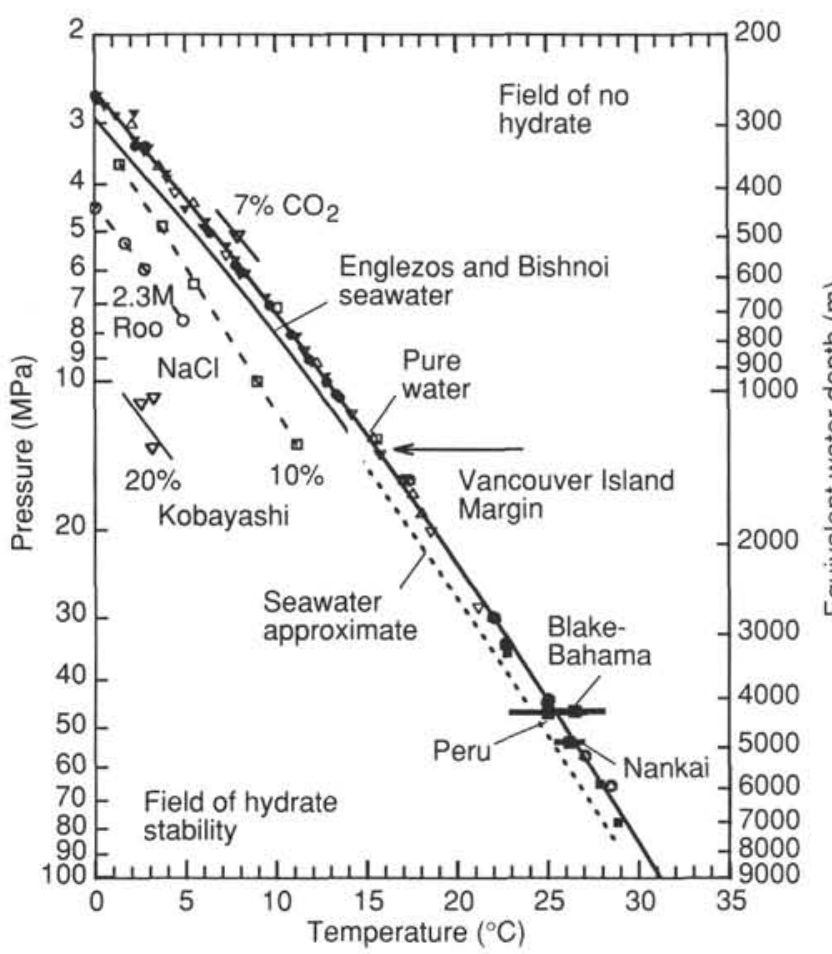

Figure 20. Stability field for pure-water methane hydrate and the effects of various other constituents (compiled by Sloan, 1990) as a function of depth (pressure). The stability field estimated for artificial seawater is from an equation of state by Englezos and Bishnoi (1988). The pressure-temperature (P-T) in-situ points for BSRs elsewhere are from Hyndman et al. (1992).

the required reflection coefficient is obtained by replacement of about $10 \%$ of the pore volume by hydrate above the BSR and enough free gas below it to reduce the velocity to $1394 \mathrm{~m} / \mathrm{s}$. Hyndman and Spence (1992) found, for the alternative limiting case of little or no reduction in velocity in an underlying gas layer, that $25 \%-35 \%$ of the pore volume must be replaced by hydrate above the BSR. Their simple model relation between percent pore volume filled with hydrate and impedance contrast is shown in Figure 23 assuming that (1) the hydrate replaces normal porosity, (2) the effect on velocity follows the same porosity-velocity relation as for normal compaction porosity reduction with depth, and (3) no change occurs in sediment bulk density. This amount of hydrate is somewhat less, but it is in general agreement with the $50 \%$ estimated from borehole geochemistry data off Middle America where the methane production and fluid expulsion both are inferred to be greater (Hyndman and Davis, 1992).

The simplest seismic modeling is vertical incidence waveform modeling. The BSR waveforms in multichannel seismic sections are remarkable in their clarity, consistency, and simplicity; in all of the areas where they have been studied, they are generally a single negative pulse that is almost the mirror image of the seafloor reflection (Fig. 22). No consistent reflector occurs above the BSR that might indicate the top of a high-velocity hydrate layer, nor is a continuous reflector present below it that might represent the base of a lowvelocity free gas layer. The waveform in most areas can be modeled by a simple downward decrease in impedance (velocity $\times$ density). Detailed modeling (Miller et al., 1991; Hyndman and Spence, 1992) has shown that a narrow range of low-velocity free gas layer thickness, less than a wavelength, can give approximately the observed waveform, but for most gas layer thicknesses the model waveform is strongly asymmetric. A very thin layer can produce the observed waveform but does not yield the required reflection coefficient. Thus, Hyndman and Spence (1992) concluded from fitting the waveform

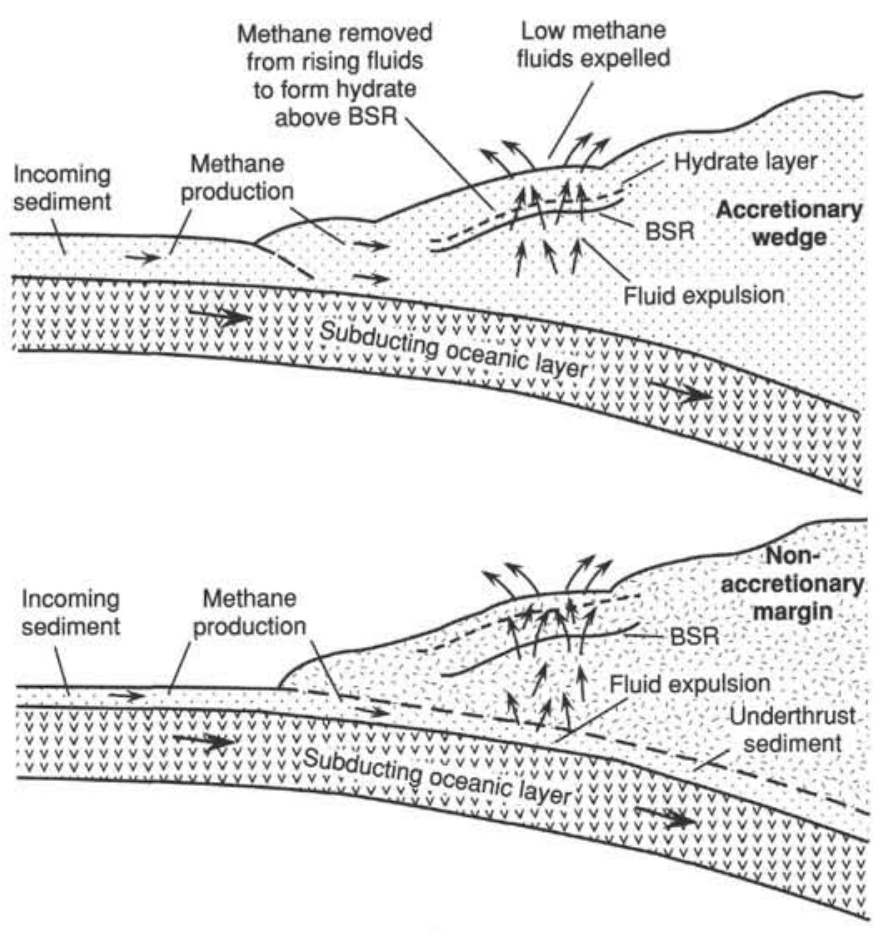

Figure 21. Fluid expulsion model for gas hydrate formation from Hyndman and Davis (1992). Methane is removed from rising pore fluids to form hydrate as they move into the hydrate stability field several hundred meters below the seafloor. The southern Vancouver Island margin is inferred to be of the type in the upper diagram.

that the top of the hydrate layer must be gradational and that probably little free gas is present beneath the BSR. However, a gas layer that is gradational downward also can produce the observed waveforms.

Amplitude and waveform vs. offset distance (AVO) can provide an important constraint on the materials that generate a reflector; AVO is particularly sensitive to the presence of free gas and is widely used as a gas detector in the petroleum industry. Small amounts of free gas (> $1 \%-10 \%$ ) reduce the $P$-wave velocity greatly but affect the $S$-wave velocity very little. For relatively unconsolidated sediments, the $P$ wave velocity is estimated to be reduced to below $1.3 \mathrm{~km} / \mathrm{s}$ and Poisson's Ratio is reduced to $0.1-0.2$, compared with about 0.48 for the upper few hundred meters of deep seafloor sediment, according to both laboratory measurements and theoretical analysis (Murphy, 1984; Domenico, 1976; Ostrander, 1984) (Fig. 24). The observed average amplitude vs. offset for the area of ODP Sites $889 / 890$ is shown in Figure 25. The predicted responses for a 15-m gradient hydrate layer model and for a 15-m gas layer model (Poisson's Ratio of 0.2) from Hyndman and Spence (1992) are shown for comparison. The hydrate-only layer clearly provides a much better fit to the data. This result indicates that a gas layer, with very low Poisson's Ratio as predicted from laboratory data and theoretical studies for concentrations greater than a few percent and as observed in the petroleum industry, must not be present. However, a moderate reduction in Poisson's Ratio and $P$-wave velocity by small concentrations of free gas (i.e., to about 0.3 and $1.5 \mathrm{~km} / \mathrm{s}$ respectively) produces a result similar to that for the hydrate-only model and thus cannot be excluded through this approach.

Singh et al. (1993) have applied a full waveform inversion technique including the far offsets to a section over the northern Cascadia Margin drill site (Sites 889/890). The procedure involves an initial long-spatial-wavelength inversion giving the RMS velocity over broad depth intervals, then a short-wavelength inversion for the waveform detail. Their inversion routine yielded a 30 -m-thick low-velocity layer below the BSR with $P$-wave velocity of $1.58 \mathrm{~km} / \mathrm{s}$ and an 


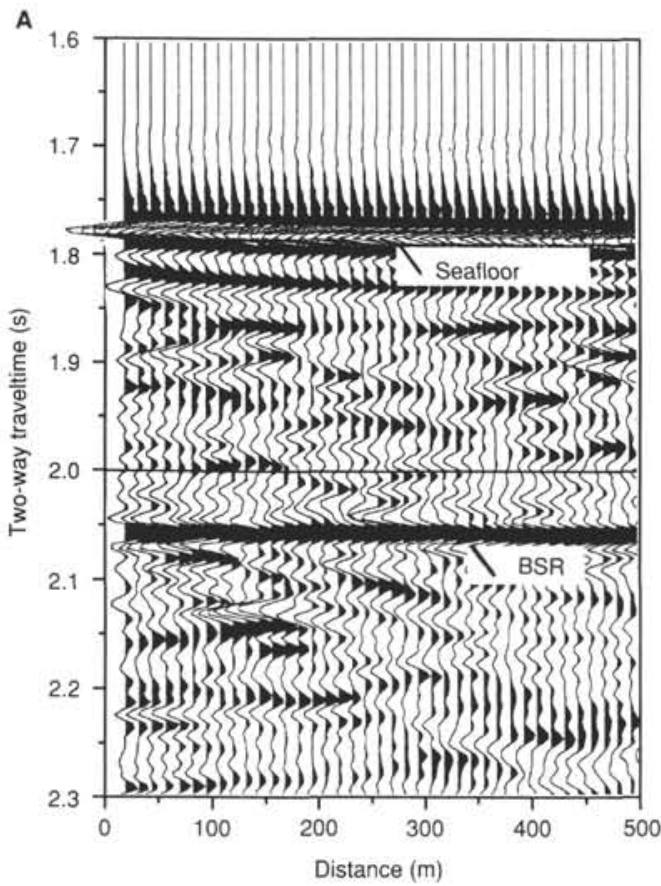

B Line 89-10

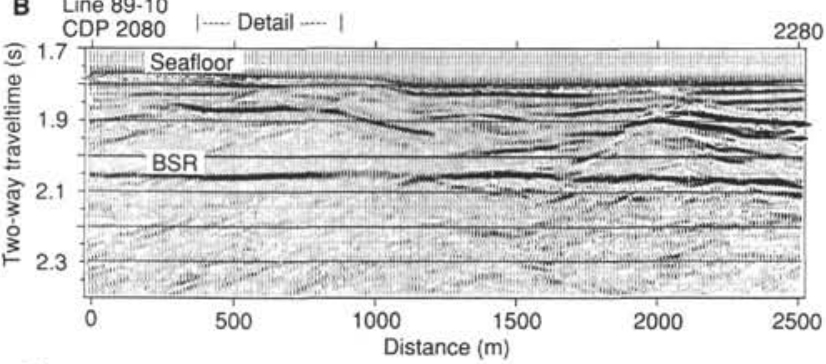

C

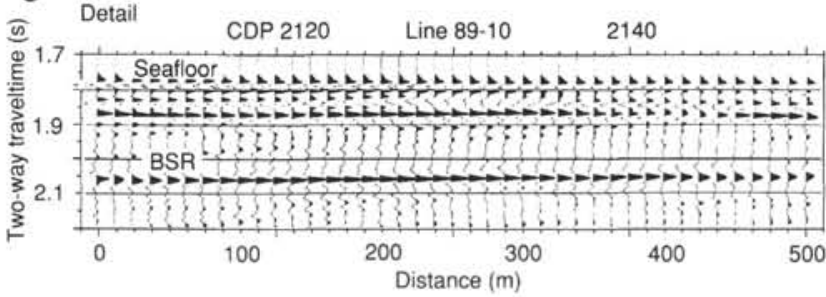

Figure 22, Examples of strong gas hydrate BSRs from southern Vancouver Island margin line 89-10 near Sites 889 and 890 . Figures $22 \mathrm{~A}$ and $22 \mathrm{C}$ show expanded scale representations of the portions of Figure 22B that are noted as "detail."

$S$-wave velocity of $0.723 \mathrm{~km} / \mathrm{s}$ (Poisson's Ratio of 0.37 ). Through a process of trial and error, they also were able to find a model with a slightly better fit having a $P$-wave velocity of $1.4 \mathrm{~km} / \mathrm{s}$ and a Poisson's Ratio of 0.32 . In their model, the nearly symmetrical BSR waveform appears to result from the interference of the reflection from the top and bottom of the layer. Their velocity values and Poisson's Ratios correspond to those predicted for less than $10 \%$ (and probably less than $1 \%$ ) free gas (see also Minshull et al., in press). However, we caution that the effects of free gas on velocity and Poisson's Ratio are sensitive to the nature of the distribution of the gas in the sediment and to the sediment grain cohesion.

The last seismic analysis technique applied to the BSR is multichannel velocity analysis. The shallow water depth and long seismic arrays used on the Cascadia margin allow a large moveout across the

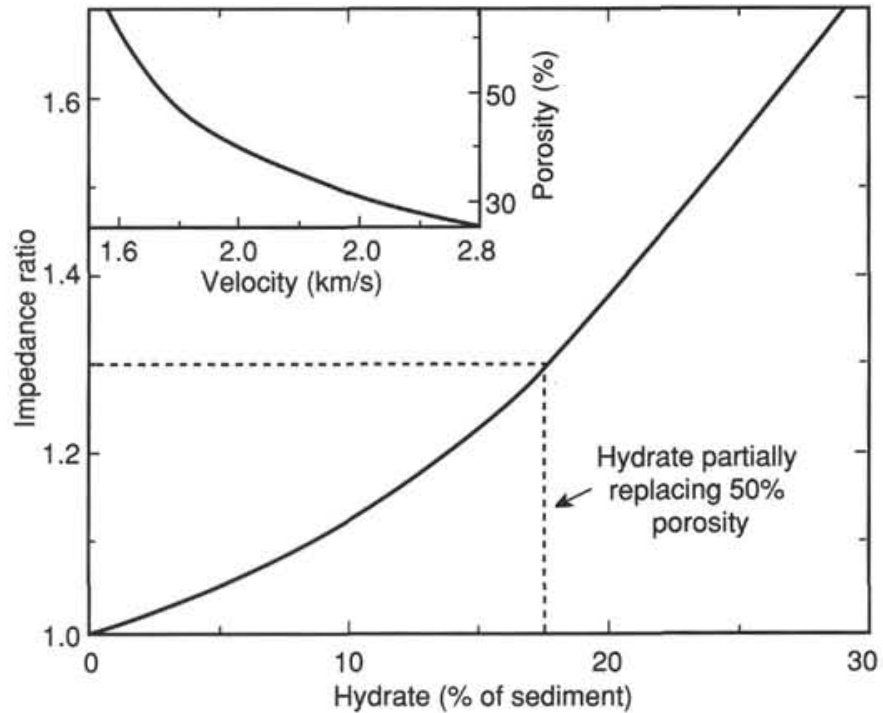

Figure 23. Semiquantitative relation between the fraction of the pore volume filled with hydrate and the impedance (and velocity) contrast. The inset gives the assumed fluid porosity-velocity relation from Hyndman et al. (1993; after Hyndman and Spence, 1992).

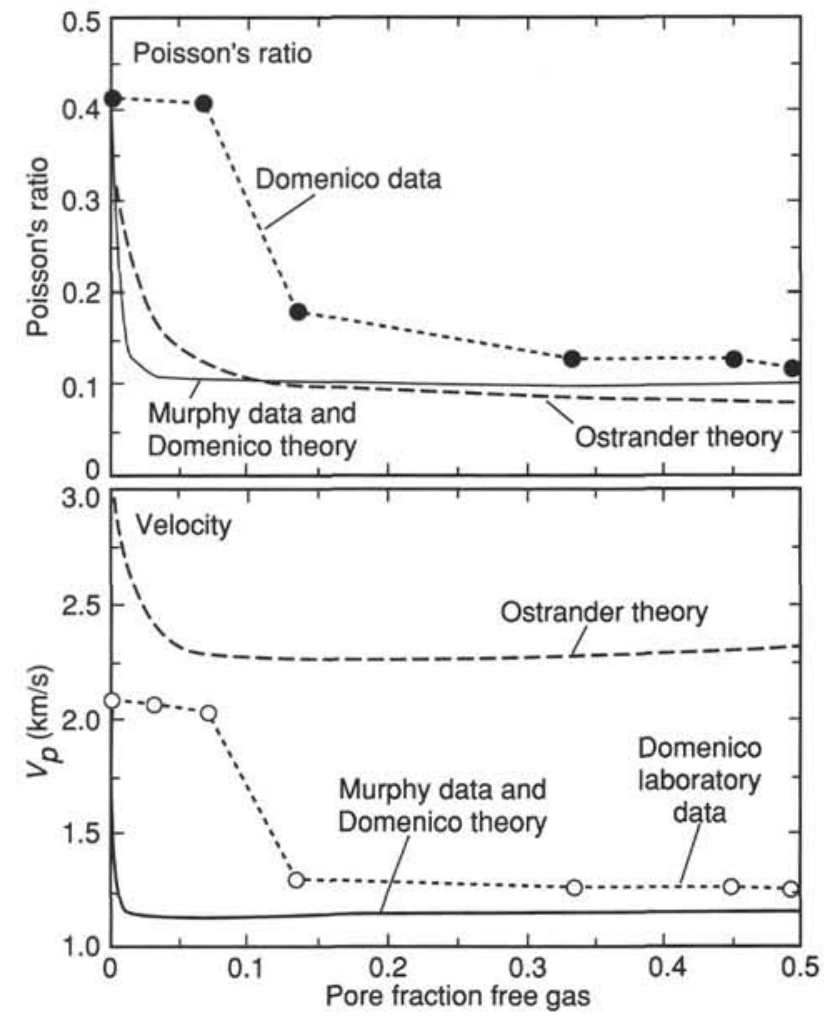

Figure 24. Laboratory and theoretical relations between free gas concentration and $P$-wave velocity and Poisson's Ratio for unconsolidated sediments (from Murphy, 1984; Domenico, 1976; Ostrander, 1984).

hydrophone array. Detailed velocity analyses were conducted on line $89-10$ in the region of Sites 889/890 (Yuan et al., in press). Variations of about $5 \mathrm{~m} / \mathrm{s}$ RMS velocity could be resolved, but interval velocities could be obtained only over depth intervals of 50-100 m; therefore, depth resolution is poor. A high-velocity layer above the BSR is evident. No low-velocity gas layer could be resolved, providing a limit 


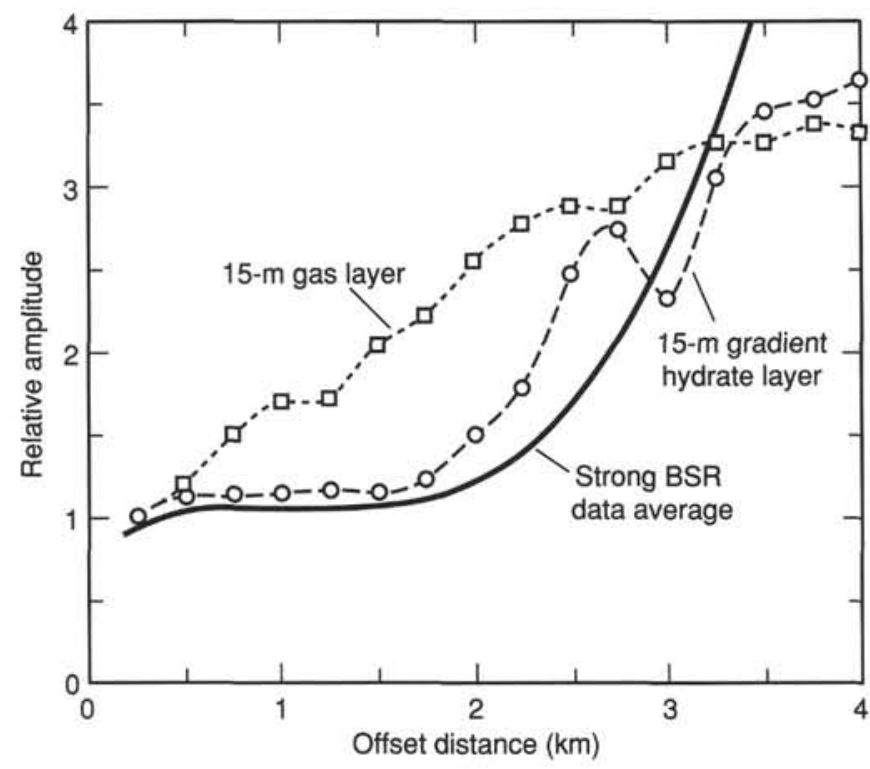

Figure 25. The average amplitude vs. offset (AVO) for an area of strong BSRs corrected for source and receiver directivity. The model curves are for a 15 -m-thick gas layer assuming a Poisson's Ratio of 0.2 , and for a 15 -m-thick tapered hydrate layer with a sharp base (after Hyndman and Spence, 1992).

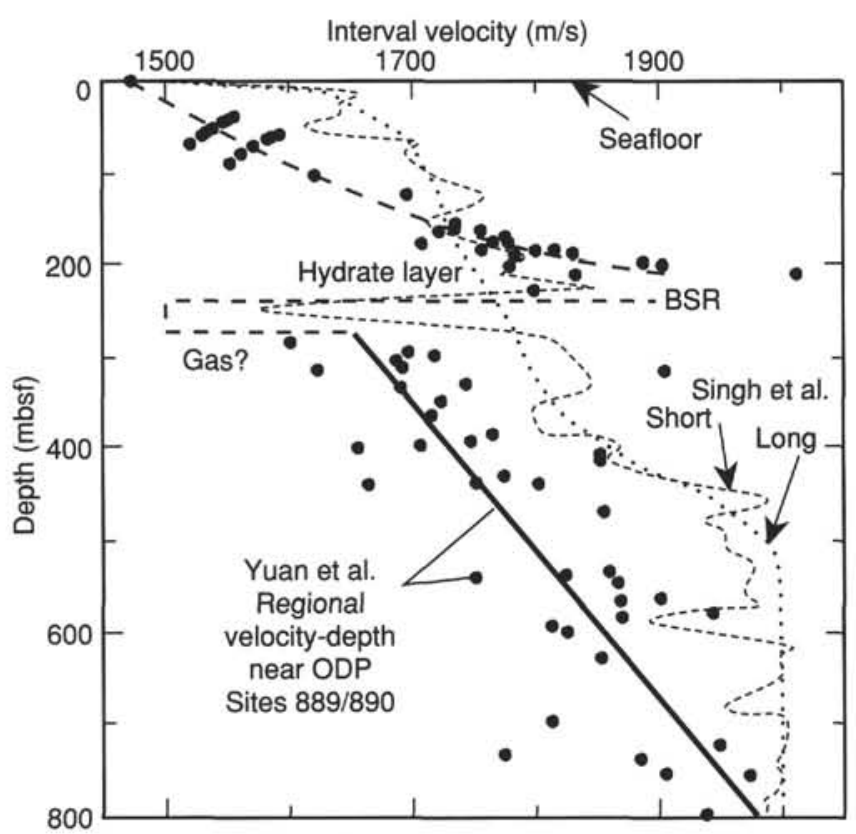

Figure 26. Interval velocities through the hydrate BSR from MCS velocity analyses near Sites 889/890 (after Yuan et al., in press) and velocities from waveform inversion by Singh et al. (1993). The dashed line gives the short spatial wavelength velocity-depth variation of Singh et al. (1993); the dotted line gives the long spatial wavelength variation.

of a maximum thickness of about $50 \mathrm{~m}$ if the velocity is less than about $1500 \mathrm{~m} / \mathrm{s}$ in the gas layer. The interval velocity profile is compared to the results of Singh et al. (1993) in Figure 26. The Singh et al. analysis is directly over Sites 889 and 890 for a small region, whereas the analysis of Yuan et al. includes a larger surrounding region; therefore, they are not exactly comparable. It should be noted that most of the points just below the BSR from the velocity analysis correspond to the average between the BSR and reflectors $50-100 \mathrm{~m}$ deeper. Thus, these points agree well with the average for that interval from the Singh et al. profile, which has a low-velocity layer beneath the BSR but higher general velocities. However, there is an unexplained difference in the velocities from the two techniques below $400 \mathrm{~m}$ (Fig. 26). The general long-wavelength velocity-depth profile of Singh et al. (1993) is higher by about $100 \mathrm{~m} / \mathrm{s}$ compared to that found for the region (Yuan et al., in press).

The principle conclusions from the seismic analyses are (1) that a zone of at least a few tens of meters thick is present immediately above the BSR with substantial concentrations of hydrate and with a gradational top, and (2) that free gas occurs beneath the BSR, but the concentrations are probably less than a few percent. The base of the gas layer may also be gradational.

\section{Some Drilling Objectives}

Some of the more important objectives for drilling on the Cascadia accretionary prism are:

1. Seismic velocity-porosity relations to allow regional porosity estimates from MCS velocity data. Differences in the relation between the basin and accretionary prism associated with cementation, tectonic stress, and pore pressure variations are particularly important. Direct downhole velocity measurements also may provide a calibration for multichannel velocity determinations.

2. Measurements, direct and indirect, of high pore pressures and fluid expulsion associated with the sediment consolidation in the accretionary prisms. If the fluid expulsion rates are very high, the flow may be evident in the downhole temperature data. This information is needed to constrain models of sediment accretion and consolidation.

3. Downhole determinations of velocity and other parameters that define the nature of the BSR. Is there a high-velocity layer above the BSR that results from high concentrations of hydrate, and is there a low-velocity layer below the BSR that results from free gas concentrations? Downhole pore-fluid organic and inorganic geochemical determinations provide important constraints on the origin of BSRs. The nature of the hydrate and free gas layers and the total amount of methane that they contain are important for evaluating the importance of hydrate and free gas methane associated with BSRs as an energy resource and a factor in global climate.

4. Downhole determination of the temperature at the BSR and thus determination of the applicable hydrate dissociation temperature. This is important for understanding the nature and formation of the BSR and as a calibration for BSR heat-flow determinations. Downhole temperature and thermal conductivity measurements are needed to resolve the discrepancy between seafloor probe and BSR heat-flow determinations on the southern Vancouver Island margin.

5. A better estimate of the thermal conductivity of the sedimentary section that can be used to improve the accuracy with which shallow thermal measurements can be extrapolated through the accretionary prism and to constrain thermal models of accretion. Determination of the factors governing velocity-thermal conductivity relations in accretionary prisms is also important.

\section{ACKNOWLEDGMENTS}

We wish to acknowledge the assistance of D. Seemann, who conducted a variety of ODP Site Survey data management and environmental impact review responsibilities. T. Lewis, R. Currie, and K. Rohr provided scientific assistance. R.P. Riddihough was responsible for meeting many of the administrative and financial responsibilities involved in approval of ODP drilling in Canadian territory. Digicon Geophysical and Haliburton Corp. were responsible for the very highquality site survey MCS reflection data. Geological Survey of Canada Contribution No. 28793. 


\section{REFERENCES}

Atwater, T., 1970. Implications of plate tectonics for the Cenozoic tectonic evolution of western North America. Geol. Soc. Am. Bull., 81:3513-3536.

1989. Plate tectonic history of the northeast Pacific and western North America. In Winterer, E.L., Hussong, D.M., and Decker, R.W. (Eds.), The Eastern Pacific Ocean and Hawaii. Geol. Soc. Am., Geol. of North America Ser., N:21-72.

Bangs, N.L.B., Westbrook, G.K., Ladd, J.W., and Buhl, P., 1990. Seismic velocities from the Barbados Ridge complex: indicators of high pore fluid pressures in an accretionary complex. J. Geophys. Res., 95:8767-8782.

Bekins, B.A., and Dreiss, S.J., 1992. A simplified analysis of parameters controlling dewatering in accretionary prisms. Earth Planet. Sci. Lett., 109:275-287.

Blackwell, D.D., 1991. Heat flow in the State of Washington and thermal conditions in the Cascade range. J. Geophys. Res., 95:19495-19516.

Bray, C.J., and Karig. D.E.. 1985. Porosity of sediments in accretionary prisms, and some implications for dewatering processes. J. Geophys. Res., 90:768-778.

Carbotte, S.M., Dixon, J.M., Farrar, E., Davis, E.E., and Riddihough, R.P., 1989. Geological and geophysical characteristics of the Tuzo Wilson Seamounts: implications for plate geometry in the vicinity of the PacificNorth America-Explorer triple junction. Can. J. Earth Sci., 26:2365-2384.

Carson, B.J., 1977. Tectonically induced deformation of deep-sea sediments off Washington and northern Oregon: mechanical consolidation. Mar: Geol., 24:289-307.

Carson, B.J., Juan, P.B., Meyers, P.B., and Barnard, W.D., 1974. Initial deep sea sediment deformation at the base of the Washington continental slope: a response to subduction. Geology, 3:561-564.

Claypool, G.E., and Kaplan, I.R., 1974. The origin and distribution of methane in marine sediments. In Kaplan, I.R. (Ed.), Natural Gases in Marine Sediments: New York (Plenum), 99-139.

Clowes, R.M., Brandon. M.T., Green, A.G., Yorath, C.J., Sutherland Brown. A., Kanasewich, E.R., and Spencer, C., 1987. LITHOPROBE-southern Vancouver Island: Cenozoic subduction complex imaged by deep seismic reflections. Can. J. Earth Sci., 24:31-51.

Clowes, R.M., Yorath, C.J., and Hyndman, R.D., 1987. Reflection mapping across the convergent margin of western Canada. Geophys. J. R. Astron. Soc., 89:79-84.

Cochrane, G.R., Lewis, B.T.R., and McClain, K.J., 1988. Structure and subduction processes along the Oregon-Washington Margin. Pure Appl. Geophys., 128:767-800.

Crosson, R.S., and Owens, T.J., 1987. Slab geometry of the Cascadia subduction zone beneath Washington from earthquake hypocenters and teleseismic converted waves. Geophys. Res. Lett., 14:824-827.

Davis, E.E., Currie, R.G., and Sawyer, B.S., 1987. Marine geophysical maps of western Canada: regional SeaMARC II acoustic image mosaics and Sea Beam bathymetry. Geol. Surv. Can., Maps 2-1987 to 17-1987.

Davis, E.E., Currie, R.G., Sawyer, B.S., and Kosalos, J.G., 1986. The use of swath bathymetric and acoustic image mapping tools in marine geoscience. Mar. Tech. Soc. J., 20:17-27.

Davis, E.E., and Hyndman, R.D., 1989. Accretion and recent deformation of sediments along the northern Cascadia subduction zone. Geol. Soc. Am. Bull., 101:1465-1480.

Davis, E.E., Hyndman, R.D., and Villinger, H., 1990. Rates of fluid expulsion across the northern Cascadia accretionary prism: constraints from new heat flow and multichannel seismic reflection data.J. Geophys. Res., 95:88698889.

Davis, E.E., and Karsten, J.L., 1986. On the asymmetric distribution of seamounts about the Juan de Fuca Ridge: ridge-crest migration over a heterogeneous asthenosphere. Earth Planet. Sci. Lett., 79:385-396.

Davis, E.E., and Seemann, D.A., 1981. A compilation of seismic reflection profiles across the continental margin of western Canada. Open-File Rep. Geol. Surv. Can., 751.

Dehler, S., 1992. Modelling of magnetic and gravity data across the Vancouver Island margin subduction zone [Ph.D. thesis]. Univ. of British Columbia, Vancouver.

\footnotetext{
Abbreviations for names of organizations and publication titles in ODP reference lists follow the style given in Chemical Abstracts Service Source Index (published by American Chemical Society).
}

Demets, C., Gordon, R.G., Argus, D.F., and Stein, S., 1990. Current plate motions. Geophys. J. Int., 101:425-478.

Domenico, S.N., 1976. Effect of brine-gas mixture on velocity in an unconsolidated sand reservoir. Geophysics, 41:882-894.

Dragert, H., Hyndman, R.D., Rogers, G.C., and Wang, K., in press. Constraints on the seismogenic zone of the northern Cascadia subduction zone from current deformation. J. Geophys. Res.

Drew, J.J., and Clowes, R.M., 1990. A re-interpretation of the seismic structure across the active subduction zone of western Canada. In Green, A.G. (Ed.), Studies of Laterally Heterogeneous Structures Using Seismic Refraction and Reflection Data. Geol. Surv. Can. Pap., 89-13:115-132.

Engebretson, D.C., Cox, A., and Gordon, R.G., 1985. Relative Motions Between Oceanic and Continental Plates in the Pacific Basin. Spec. Pap.Geol. Soc. Am., 206.

Engebretson, D.C., Cox, A., and Thompson, G.A., 1984. Correlation of plate motions with continental tectonics: Laramide to Basin and Range. Tectonics, 3:115-120.

Englezos, P., and Bishnoi, P.R., 1988. Predictions of gas hydrate formation conditions in aqueous solutions. Am. Inst. Chem. Eng., 34:1718-1721.

Ferguson, I.J., Westbrook, G.K., Langseth, M.G., and Thomas, G.P., 1993. Heat flow and thermal models of the Barbados Ridge accretionary complex. J. Geophys. Res., 98:4121-4142.

Hayes, D.E., and Ewing, M., 1970. Pacific Plate boundary structure. In Maxwell, A. (Ed.), The Sea: New York (Wiley), 29-72,

Holbrook, W.S., and Paull, C.K., 1992. Seismic studies of gas hydrate structure, Blake Ridge and Carolina Rise. Woods Hole Oceanogr. Inst., Dep. Geol. Geophys., Cruise Rep., CH-06-92.

Hyndman, R.D., 1983. Geothermal heat flux, Juan de Fuca Plate map. Juan de Fuca Plate Map Ser., Pacific Geosci. Centre, Geol. Surv, Can.

Hyndman, R.D., and Davis, E.E., 1992. A mechanism for the formation of methane hydrate and seafloor bottom simulating reflectors by vertical fluid expulsion. J. Geophys. Res., 97:7025-7041.

Hyndman, R.D., Foucher, J.P., Yamano, M., Fisher, A., Berner, U., Brückmann, W., Byrne, T., Chabernaud, T., Firth, J.V., Gamo, T., Gieskes, J.M., Hill, I.A., Karig, D.E., Kastner, M., Kato, Y., Lallemand, S., Lau, R., Maltman, A.J., Moore, G.F., Moran, K., Olafsson, G., Owens, W.H., Pickering, K.T., Siena, F., Taira, A., Taylor, E., Underwood, M.B., Wilkinson, C.. and Zhang, J., 1992. Deep sea bottom-simulating-reflectors: calibration of the base of the hydrate stability field as used for heat flow estimates. Earth Planet. Sci. Lett., 109:289-302.

Hyndman, R.D., and Hamilton, T.S., 1993. Queen Charlotte area Cenozoic tectonics and volcanism and their association with relative plate motions along the northeastern Pacific margin. J. Geophys. Res., 98:14257-14277.

Hyndman, R.D., Moore, G.F., and Moran, K., 1993. Velocity, porosity, and pore-fluid loss from the Nankai subduction zone accretionary prism. In Hill, I.A., Taira, A., Firth, J.V., et al., Proc. ODP, Sci. Results, 131: College Station, TX (Ocean Drilling Program), 211-220.

Hyndman, R.D., Riddihough, R.P., and Herzer, R., 1979. The Nootka fault zone: a new plate boundary off western Canada. Geophys. J. R. Astron. Soc., 58:667-683.

Hyndman, R.D., and Spence, G.D., 1992. A seismic study of methane hydrate seafloor bottom-simulating reflectors. J. Geophys. Res., 97:6683-6698.

Hyndman, R.D., and Wang, K., 1993. Thermal constraints on the zone of major thrust earthquake failure: the Cascadia subduction zone. J. Geophys. Res., 98:2039-2060.

Hyndman, R.D., Wang, K., Yuan, T., and Spence, G.D., in press. Tectonic sediment thickening, fluid expulsion, and the thermal regime of subduction zone accretionary prisms: the Cascadia margin off Vancouver Island. $J$. Geophys. Res.

Hyndman, R.D., Yorath, C.J., Clowes, R.M., and Davis, E.E., 1990. The northern Cascadia subduction zone at Vancouver Island: seismic structure and tectonic history. Can. J. Earth Sci., 27:313-329.

Johnson, S.Y., 1984. Evidence for a margin truncating transcurrent fault (pre-late Eocene) in western Washington. Geology, 12:538-541.

Keen, C.E., and Hyndman, R.D., 1979. Geophysical review of the continental margins of eastern and western Canada. Can. J. Earth Sci., 16:712-747.

Kulm, L.D., von Huene, R., et al., Init. Repts. DSDP, 18: Washington (U.S. Govt. Printing Office).

Kvenvolden, K.A., 1988. Methane hydrate-a major reservoir of carbon in the shallow geosphere? Chem. Geol., 71:41-51.

Kvenvolden, K.A., and McDonald, T.J., 1985. Gas hydrates of the Middle America Trench-Deep Sea Drilling Project Leg 84. In von Huene, R., Aubouin, J., et al., Init. Repts. DSDP, 84: Washington (U.S. Govt. Printing Office), 667-682. 
Langton, S., 1993. The seismic structure of the Tofino Basin and underlying accreted terranes [M.S. thesis]. Univ. of Victoria, Victoria, British Columbia, Canada

LePichon, X., Henry, P., and Lallemant, S., 1990. Water flow in the Barbados accretionary complex. J. Geophys. Res., 95:8945-8967.

Lewis, T.J., Bentkowski, W.H., Davis, E.E., Hyndman, R.D., Souther, J.G., and Wright, J.A., 1988. Subduction of the Juan de Fuca Plate: thermal consequences. J. Geophys. Res., 93:15207-15225.

Lewis, T.J., Bentkowski, W.H., and Hyndman, R.D., 1991. Crustal temperatures near the LITHOPROBE southern Canadian Cordilleran transect. Can. J. Earth Sci., 29:1197-1214.

MacDonald, G.J., 1990. Role of methane clathrates in past and future climates. Clim. Change, 16:247-281.

MacKay, M.E., Moore, G.F., Cochrane, G.R., Moore, J.C., and Kulm, L.D., 1992. Landward vergence and oblique structural trends in the Oregon Margin accretionary prism: implications and effect on fluid flow. Earth Planet. Sci. Lett., 109:477-491.

MacLeod, N.S., Tiffin, D.L., Snavely, P.D., and Currie, R.G., 1977. Geologic interpretation of magnetic and gravity anomalies in the Strait of Juan de Fuca, U.S.-Canada. Can. J. Earth Sci., 14:223-238.

Massey, N.W.D., 1986. The Metchosin Igneous Complex, southern Vancouver Island: ophiolite stratigraphy developed in an emergent island setting. Geology, 14:602-605.

McIver, R.D., 1974. Hydrocarbon gas (methane) in canned Deep Sea Drilling Project core samples. In Kaplan, I.R. (Ed.), Natural Gases in Marine Sediments: New York (Plenum), 63-69.

Miller, J.J., Lee, M.W., and von Huene, R., 1991. A quantitative analysis of gas hydrate phase boundary reflection (BSR), offshore Peru. AAPG Bull., 75:910-924.

Minshull, T., Singh, S.C., and Westbrook, G.K., in press. Seismic velocity structure at a gas hydrate reflector, offshore western Colombia, from full waveform inversion. J. Geophys. Res.

Minshull, T., and White, R., 1989. Sediment compaction and fluid migration in the Makran accretionary prism. J. Geophys. Res., 94:7387-7402.

Moore, J.C., and Vrolijk, P., 1992. Fluids in accretionary prisms. Rev. Geophys. Space Phys., 30:113-135.

Murphy, W.F., 1984. Acoustic measures of partial gas saturation in tight sandstones. J. Geophys. Res., 89:11549-11559.

Nisbet, E.G., 1990. The end of the ice age. Can. J. Earth Sci., 27:148-157.

Nishimura, C., Wilson, D.S., and Hey, R.N., 1984. Pole of rotation analysis of present day Juan de Fuca Plate motion. J. Geophys. Res., 89:10283-10290.

Ostrander, W.J., 1984. Plane-wave reflection coefficients for gas sands at non-normal angles of incidence. Geophysics, 49:1637-1648.

Pollitz, F.F., 1988. Episodic North America and Pacific plate motions. Tectonics, 7:711-726.

Riddihough, R.P., 1979. Structure and gravity of an active margin-British Columbia and Washington. Can. J. Earth Sci., 16:350-363.

, 1984. Recent movements of the Juan de Fuca Plate system. $J$. Geophys. Res., 89:6980-6994.

Riddihough, R.P., and Hyndman, R.D., 1991. Modern plate tectonic regime of the continental margin of western Canada. In Gabrielse, H., and Yorath, C.J. (Eds.), Geology of the Cordilleran Orogen in Canada. Geol. Surv. Can., Geol. in Can. Ser., 4:435-455.

Rogers, G.C., 1983. Some comments on the seismicity of the northern Puget Sound-southern Vancouver Island Region. In Earthquake Hazards of the Puget Sound Region. Open-File Rep.-U.S. Geol. Surv., 83-19:19-39.

Rohr, K.K., 1987. Anatomy of the deformation front, Vancouver Island, Canada. Eos, 68:1467.

Shi, Y., and Wang, C.-Y., 1988. Generation of high pore pressures in accretionary prisms: inferences from the Barbados Subduction Complex. J. Geophys. Res., 93:8893-8909.

Shipley, T.H., and Didyk, B.M., 1982. Occurrence of methane hydrates offshore southern Mexico. In Watkins, J.S., Moore, J.C., et al., Init. Repts. DSDP, 66: Washington (U.S. Govt. Printing Office), 547-555.

Shipley, T.H., Houston, M.H., Buffler, R.T., Shaub, F.J., McMillen, K.J., Ladd, J.W., and Worzel, J.L., 1979. Seismic evidence for widespread possible gas hydrate horizons on continental slopes and rises. AAPG Bull., 63:2204-2213.

Shouldice, D.H., 1971. Geology of the western Canadian continental shelf. Bull. Can. Pet. Geol., 19:405-436.
1973. Western Canadian continental shelf. Mem.-Can. Soc. Pet. Geol., 1:7-35.

Singh, S.C., Minshull, T.A., and Spence, G.D., 1993. Velocity structure of a gas hydrate reflector. Science, 260:204-207.

Sloan, E.D., 1990. Clathrate Hydrates of Natural Gases: New York (Marcel Dekker).

Snavely, P.D., Jr., 1987. Tertiary geologic framework, neotectonics, and petroleum potential of the Oregon-Washington continental margin. In Scholl, D.W., Grantz, A., and Vedder, J.G. (Eds.), Geology and Resource Potential of the Continental Margin of Western North America and Adjacent Ocean Basins-Beaufort Sea to Baja California. Circum-Pac. Counc. Energy Miner. Resour., Earth Sci. Ser., 6:305-336.

Spence, G.D., Clowes, R.M., and Ellis, R.M., 1985. Seismic structure across the active subduction zone of western Canada. J. Geophys. Res., 90:67546772 .

Spence, G.D., Hyndman, R.D., et al., 1991. Seismic structure of the northern Cascadia accretionary prism: evidence from new multichannel seismic reflection data. In Meissner, R., Brown, L., Birbaiet, W., Franke, K., Fuchs, K., and Seifert, F. (Eds.), Continental Lithosphere, Deep Seismic Reflection. Am. Geophys. Union, Geodyn. Ser., 22:257-263.

Spence, G.D., Hyndman, R.D., Langton, S.G., Davis, E.E., and Yorath, C.J. 1991. Multichannel seismic reflection profiles across the Vancouver Island continental shelf and slope. Open-File Rep., Geol. Surv. Can., 2391.

Stock, J.M., and Molnar, P., 1988. Uncertainties and implications of the Late Cretaceous and Tertiary positions of North America relative to the Farallon, Kula, and Pacific plates. Tectonics, 6:1339-1384.

Tabor, R.W., and Cady, W.M., 1978. The structure of the Olympic Mountains, Washington-analysis of a subduction zone. Geol. Surv. Prof. Pap. U.S., 1033 .

Tiffin, D.L., Cameron, B.E.B., and Murray, J.W., 1972. Tectonic and depositional history of the continental margin off Vancouver Island, B.C. Can. J. Earth Sci., 9:280-296.

von Huene, R., and Scholl, D.W., 1991. Observations at convergent margins concerning sediment subduction, subduction erosion, and the growth of the continental crust. Rev. Geophys., 29:279-316.

Wang, K., Hyndman, R.D., and Davis, E.E., 1993. Thermal effects of sediment thickening and fluid expulsion in accretionary prisms. J. Geophys. Res. 98:9975-9984.

Warner, M., 1990. Absolute reflection coefficients from deep seismic reflections. Tectonophysics, 173:15-23.

Wells, R.E., Engebretson, D.C., Snavely, P.D., and Coe, R.S., 1984. Cenozoic plate motions and the volcano-tectonic evolution of western Oregon and Washington. Tectonics, 3:275-294.

Westbrook, G.K., 1991. Geophysical evidence for the role of fluids in accretionary wedge tectonics. Philos. Trans. R. Soc. London A, 335:227-242.

Wilson, D.S., 1988. Tectonic history of the Juan de Fuca Ridge over the last 40 million years. J. Geophys. Res., 93:11863-11876.

1989. Deformation of the so-called Gorda Plate. J. Geophys. Res., 94:3065-3075.

Yamano, M., Uyeda, S., Aoki, Y., and Shipley, T.H., 1982. Estimates of heat flow derived from gas hydrates. Geology, 10:339-343.

Yorath, C.J., 1980. The Apollo structure in Tofino Basin, Canadian Pacific continental margin. Can. J. Earth Sci., 17:758-775.

1987. Petroleum geology of the Canadian Pacific continental margin. In Scholl, D.W., Grantz, A., and Vedder, J.G. (Eds.), Geology and Resource Potential of the Continental Margin of Western North America and Adjacent Ocean Basins-Beaufort Sea to Baja California. CircumPac. Counc. Energy Miner. Resour., Earth Sci. Ser., 6:283-304.

-, in press. Geological structure along the Lithoprobe corridor, Vancouver Island. Geol. Surv. Can. Bull.

Yorath, C.J., Clowes, R.M., MacDonald, R.D., Spencer, C., Davis, E.E., Hyndman, R.D., Rohr, K., Sweeney, J.F., Currie, R.G., Halpenny, J.F., and Seemann, D.A., 1987. Marine multichannel seismic reflection, gravity and magnetic profiles-Vancouver Island continental margin and Juan de Fuca Ridge. Open-File Rep,-Geol. Surv. Can., 1661.

Yuan, T., Spence, G.D., and Hyndman, R.D., in press. Seismic velocities and porosities in the accretionary wedge sediments at the Cascadia Margin. $J$. Geophys. Res.

\section{Ms 146IR-002}

